Ks. Antoni SWOBODA*

\title{
OJCOSTWO BOŻE I OJCOSTWO LUDZKIE W UJĘCIU ŚW. AUGUSTYNA
}

Temat ojcostwa i roli ojca, jaką spełnia on w rodzinie, stanowi przedmiot zainteresowania nie tylko w czasach współczesnych, ale był także podejmowany w starożytności zarówno niechrześcijańskiej, jak i w okresie, w którym rodziło się i rozwijało chrześcijaństwo. Gdy chodzi o niechrześcijańskie środowisko łacińskie, to częstotliwość występowania rzeczownika pater, tak w odniesieniu do ojca ziemskiego, jak i do bóstwa jest dość znaczna. Potwierdzają to np., w przypadku literatury łacińskiej odnoszącej się do przykładowo biorąc okresu od III w. prz. Chr. do V w. po Chr., pisma autorów zebrane w $B i$ bliotheca Teubneriana Latina, w których aż 3030 razy występuje rzeczownik pater użyty w nominativus singularis. Przegląd literatury tego okresu pozwala zauważyć, iż na temat ojca i to z różnych punktów widzenia, wypowiadali się przykładowo, począwszy od ojca literatury łacińskiej Liwiusza Andronikusa (III prz. Chr.) tacy autorzy jak komediopisarz Plaut (ok. 250-184 prz. Chr.) ${ }^{1}$ (Amphitrus, Captivi, Cistellaria), Katon Starszy (234-149 p. Chr.) (De agri cultura), poeci Wergiliusz (70-19 prz. Chr.) (Aeneis) i Horacy (65-8 prz. Chr.) (Carmina, Epistulae, Sermones).

W tym miejscu nie można pominąć nauczania filozofa, polityka i mówcy Cycerona (106-43 prz. Chr.) (In C. Verrem oratio, De oratore, De divinatione, De natura deorum, De officiis, De re publica, Tusculanae disputationes, Epistulae ad Atticum, Epistulae ad familiares), wspomnieć należy także o wybitnym uczonym rzymskim i encyklopedyście Warronie (116-27 prz. Chr.) (De lingua Latina).

Na uwagę zasługują również przemyślenia filozofa i moralisty Seneki (4 prz. Chr. - 65 po Chr.) (De beneficiis, Consolatio ad Marciam, Consolatio ad Helviam matrem, Epistulae morales ad Lucilium), a także największego historyka rzymskiego, mówcy, polityka, Tacyta (ok. 55-120) (Annales) oraz jego przyjaciela Pliniusza Młodszego (ok. 61 - ok. 113) (Epistulae, Panegyricus).

${ }^{*}$ Ks. dr hab. Antoni Swoboda, prof. UAM - profesor nadzwyczajny w Zakładzie Teologii Patrystycznej na Wydziale Teologicznym Uniwersytetu im. Adama Mickiewicza w Poznaniu; e-mail: aswoboda@amu.edu.pl.

${ }^{1}$ Przy kolejnych autorach niechrześcijańskich, jak i chrześcijańskich będą podawane tylko dzieła z największą ilością wystąpień, zaś odniesienia pojedyncze będą pomijane. 
Wielu wiadomości na temat ojca dostarcza także przyjaciel Pliniusza Młodszego, pisarz Swetoniusz (ok. 70-140) (De vita Caesarum).

Gdy chodzi o środowisko chrześcijańskie, to analizując pisma autorów wczesnochrześcijańskich wydane $\mathrm{w}$ serii Library of Latin Texts - Series $A$ przez „Brepols” możemy się przekonać, że częstotliwość występowania tego rzeczownika w nominativus singularis, również w odniesieniu do ojca ziemskiego, jak i Boga Ojca, w literaturze do V w., jest o wiele większa i wynosi 10804 wystąpień. Spośród autorów tego okresu najczęściej pojawia się ten rzeczownik u retora i apologety Tertuliana (ok. 155 - ok. 220) (Adversus Praxeam, Adversus Marcionem), filozofa Laktancjusza (ok. 250-330) (Divinarum institutionum), retora Mariusza Wiktoryna (ok. 300-363) (Adversus Arium), św. Hilarego z Poitiers (ok. 315-367) (De Trinitate), św. Ambrożego z Mediolanu (ok. 339-397) (Expositio Evangelii secundum Lucam, De fide, De Spiritu Sancto, De Trinitate), św. Hieronima ze Strydonu (ok. 347-419) (Epistulae, De Spiritu Sancto, De nominibus Hebraicis, Commentaria in Isaiam), a w szczególności u św. Augustyna biskupa Hippony (354-430) (Epistulae, In Joannis Evangelium tractatus, Enarrationes in Psalmos, Sermones de Scripturis, De civitate Dei, Contra Maximum episcopum Arianorum, De Trinitate).

$\mathrm{W}$ odróżnieniu od pojęcia pater w starożytności funkcjonowało także pojęcie paterfamilias pisane łącznie ${ }^{2}$ oraz $\mathrm{w}$ postaci rozłączonych rzeczowników pater familias, które również wskazywało na ojca rodziny także $\mathrm{w}$ aspekcie prawnym ${ }^{3}$.

Gdy chodzi o rzeczownik pisany łącznie (paterfamilias) ${ }^{4}$, to w przypadku autorów niechrześcijańskich występuje on przede wszystkim u wspomnianego już Marka Tuliusza Cycerona (De inventione, Topica) oraz u historyka rzymskiego Ammiana Marcellina (ok. 333-400) (Rerum gestarum libri qui supersunt).

Natomiast $u$ autorów chrześcijańskich jego obecność jest raczej sporadyczna. Najczęściej spotkać można ten wyraz u św. Cypriana (200/210-258) (Epistulae), św. Klemensa Rzymskiego (†101) (Epistula ad Corinthios), św. Ambrożego z Mediolanu (Expositio Evangelii secundum Lucam), św. Hieronima (Commentaria in Matthaeum, Adversus Jovinianum) oraz św. Augustyna (Sermones, De Genesi contra Manichaeos, In Joannis Evangelium tractatus, Enarrationes in Psalmos) i Sulpicjusza Sewera (ok. 363-420) (Dialogorum libri II).

${ }^{2}$ Rzeczownik ten pisany łącznie: paterfamilias podaje Alojzy Jougan (Stownik kościelny łacińsko-polski, Warszawa 1992, 484) w formie pater-familias. Również w formie łącznej występuje u Józefa Korpantego (Stownik łacińsko-polski, t. 2, Warszawa 2003, 409). Podaje go także Database of Latin Dictionaries (DLD) by CTLO, wyd. Brepols Publishers, Turnhout 2013, za A. Forcellini, Lexicon Totius Latinitatis, Patavii 1965 (impressio anastatica ex editione aa. 1864-1926).

${ }^{3}$ Rzeczownik pater familias pisany rozłącznie podaje Marian Plezia (IV 46, s.v. pater). W tej formie spotykamy także u Ferruccio Calonghi (Dizionario Latino-italiano, vol. 1, Torino 1972, 1970) i Angelo Perugini (Dizionario Italiano-latino, Città del Vaticano 1976, 1330).

${ }^{4}$ Także i tutaj będą podane tylko najczęstsze wystąpienia tego rzeczownika. 
Pater familias pisane rozdzielnie częściej pojawia się w źródłach. Pod tym względem na szczególną uwagę spośród autorów niechrześcijańskich zasługuje Katon Starszy (De agri cultura), następnie historyk, biograf i poeta Korneliusz Nepos (De viris illustribus), a przede wszystkim Cyceron (Pro P. Quinctio oratio, In C. Verrem orationes, In L. Calpurnium Pisonem oratio, In L. Sergium Catilinam orationes, Pro L. Valerio Flacco oratio, Pro M. Tullio oratio, Pro P. Quinctio oratio, Pro rege Deiotaro oratio, De oratore, De legibus, De lingua Latina). To pojęcie spotykamy także u pisarza Waleriusza Maksimusa (I w.) (Facta et dicta memorabilia), historyka Pliniusza Starszego (23-79) (Naturalis historia), Swetoniusza (ok. 69-130) (De vita Caesarum), prawnika Gajusza (ok. 110-180) (Institutiones), filozofa, retora i pisarza Apulejusza (ok. 124 - po 170) (Florida), również pisarza, a zarazem filozofa Makrobiusza (IV/V w.) (Saturnalia), historyka rzymskiego Ammiana Marcellina (Rerum gestarum libri qui supersunt). Godne uwagi są także Iuris Romani anteiustiniani fragmenta Vaticana czy też pisma Scriptores Historiae Augustae (Aelius Lampridius).

W porównaniu z tymi źródłami u autorów chrześcijańskich liczba wystąpień pater familias jest nieco mniejsza. To określenie obecne jest zwłaszcza u Tertuliana (Adversus Marcionem), Laktancjusza (Divinae institutiones), św. Hieronima (Epistulae), św. Ambrożego (De Abraham, Expositio Evangelii secundum Lucam), Zenona z Werony († ok 371) (Tractatus) i św. Augustyna (Enarrationes in Psalmos, Sermones, Contra Faustum), a także we wspomnianych już Iuris Romani anteiustiniani fragmenta Vaticana.

Prócz przytoczonych w tym miejscu rzeczowników jest jeszcze jeden, a mianowicie paternitas oznaczający ojcostwo. Okazuje się jednak, że w literaturze łacińskiej niechrześcijańskiej zebranej w cytowanej już Bibliotheca Teubneriana Latina nie występuje. Natomiast, gdy chodzi o literaturę wczesnochrześcijańską do $\mathrm{V}$ w. to ilość jego wystąpień w nominativus singularis jest bardzo mała i wynosi tylko 47. Spotkać go można m.in. u Mariusza Wiktoryna, Ambrozjastra (IV w.), biskupa Rawenny, Piotra Chryzologa (ok. 380450), św. Augustyna, św. Eucheriusza z Lyonu (V w.), a także u św. Hieronima.

Tematyce roli ojca w rodzinie, gdy chodzi o starożytne środowisko łacińskie do $\mathrm{V}$ w., poświęconych zostało wiele prac, których wykaz znajduje się w L'Annee Philologique dostępnym także drogą elektroniczną. Tak więc określeniu pater familias pisanemu rozłącznie poświęcone są prace takich autorów jak np. Nunzia Donadio ${ }^{5}$, Jean Christian Dumont ${ }^{6}$, Marcos Ruiz Sánchez ${ }^{7}$. Ze

${ }^{5}$ Por. N. Donadio, «Iudicium domesticum», riprovazione sociale e persecuzione pubblica di atti commessi da sottoposti alla «patria potestas», „Index” 40 (2012) 175-195.

${ }^{6}$ Por. J.Ch. Dumont, L'imperium du pater familias, w: Parenté et stratégies familiales dans l'Antiquité romaine, ed. J. Andreau - H. Bruhns, Paris, Paris 1990, 475-495.

${ }^{7}$ Por. M. Ruiz Sánchez, Padres e hijos en la sociedad, en el mito y en la literatura latinas, w: Visiones mítico-religiosas del padre en la Antigüedad clásica, ed. M. Ruiz Sánchez, Madrid 2004, 7-12. 
starszych opracowań wymienić należy Ricardo Astolfi ${ }^{8}$, Luigi Capogrossi Colognesi ${ }^{9}$, Alfredo Mordechai Rabello ${ }^{10}$, Francesco Maria Robertis ${ }^{11}$, Giovanni Runchina $^{12}$, Richard P. Sallera ${ }^{13}$, Alfonso Traina ${ }^{14}$ czy też Antonie Wlosoka ${ }^{15}$.

Nie brak również opracowań powiązanych z pojęciem paterfamilias pisanym łącznie. W tym zakresie posiadamy opracowania powstałe już dość dawno, np. autorstwa Antti Arjava ${ }^{16}$, Williama W. Bucklanda ${ }^{17}$, Johna Anthony'ego Crooka ${ }^{18}$, Josepha Dénoyeza ${ }^{19}$, Filippo Gallo ${ }^{20}$, A.M. Rabello ${ }^{21}$ oraz Pasquale $\mathrm{Voci}^{22}$.

Pewnym uzupełnieniem literatury na interesujący nas temat są opracowania, w których autorzy starają się przybliżyć znaczenie ojcostwa fizycznego i duchowego. Stąd też na uwagę zasługują m.in. przemyślenia takich autorów jak: Florence Khodoss ${ }^{23}$, Anne Lefebvre-Teillard ${ }^{24}$, Dieter Lenzen ${ }^{25}$, Maria

${ }^{8}$ Por. R. Astolfi, Costituzione di servitù e destinazione del padre di famiglia, „Bullettino dell'Istituto di Diritto Romano" 72 (1969) 181-201.

${ }^{9}$ Por. L. Capogrossi Colognesi, Ancora sui poteri del pater familias, „Bullettino dell'Istituto di Diritto Romano" 73 (1970) 357-425.

${ }^{10}$ Por. A.M. Rabello, L'acquisto della patria potestas, „Labeo” 21 (1975) 172-192.

${ }^{11}$ Por. M.F. de Robertis, I limiti spaziali al potere del pater familias, „Labeo” 29 (1983) 164-174.

${ }^{12}$ Por. G. Runchina, Polemica filosofica e dottrinale nel „,De ira Dei” di Lattanzio, „Annali della Facoltà di Lettere e Filosofia dell’Università di Cagliari” 6 (1985) 159-181.

${ }^{13}$ Por. R.P. Saller, «Pater familias», «mater familias», and the gendered semantics of the Roman household, CPh 94 (1999) fasc. 2, 182-197.

${ }^{14}$ Por. A. Traina, Pater familiae, „Latinitas” 12 (1964) 225-229.

${ }^{15}$ Por. A. Wlosok, Vater und Vatervorstellungen in der römischen Kultur, w: Das Vaterbild im Abendland, hrsg. H. Tellenbach, Stuttgart 1978, 18-54 i 192-200.

${ }^{16}$ Por. A. Arjava, Paternal power in late antiquity, JRS 88 (1998) 147-165.

${ }^{17}$ Por. W.W. Buckland, Diligens paterfamilias, w: Studi in onore di Pietro Bonfante nel XL anno d'insegnamento, ed. E. Albertario - P. de Francisci - P. Ciapessoni, vol. 2, Milano 1930, 85-108.

${ }^{18}$ Por. J.A. Crook, Patria potestas, CQ 17 (1967) 113-122.

${ }^{19}$ Por. J. Dénoyez, Le paterfamilias et l'évolution de ça position, w: Synteleia Vincenzo ArangioRuiz, ed. A. Guarino - L. Labruna, Napoli 1964, 441-449.

${ }^{20}$ Por. F. Gallo, Osservazioni sulla signoria del paterfamilias in epoca arcaica, w: Studi in onore di Pietro de Francisci, vol. 1, Milano 1956, 193-236.

${ }^{21}$ Por. A.M. Rabello, L'acquisto della patria potestas sul proprio filius alla morte del paterfamilias, „Revue Internationale des Droits de L'Antiquité”18 (1971) 784; tenże, L'acquisto della patria potestas, s. 172-192.

${ }^{22}$ Por. P. Voci, Storia della patria potestas da Augusto a Diocleziano, „Iura” 31 (1980) 37-100; tenże, Storia della patria potestas da Costantino a Giustiniano, „Studia et Documenta Historiae et Iuris" 51 (1985) 1-72.

${ }^{23}$ Por. F. Khodoss, L'enfant est le père de l'homme, w: Saint Augustin, ed. P. Ranson, Paris 1988, 348-355.

${ }^{24}$ Por. A. Lefebvre-Teillard, «Pater is est quem nuptiae demonstrant»: jalons pour une histoire de la présomption de paternité, „Revue Historique de Droit Français et Étranger” 69 (1991) fasc. 3, 331-341.

${ }^{25}$ Por. D. Lenzen, Vaterschaft: vom Patriarchat zur Alimentation, Reinbek bei Hamburg 1991. 
Antonia Mancuso $^{26}$, Christoph Johannes Markschies ${ }^{27}$, Antonio Guarino ${ }^{28}$, Anna De Francesco ${ }^{29}$, Marcos Ruiz Sánchez ${ }^{30}$, Elena Conde Guerri ${ }^{31}$, Antonella Borgo ${ }^{32}$ Paola Luigia Carucci ${ }^{33}$. Z polskich prac lub tłumaczeń na język polski warto wymienić prace Petera Browna ${ }^{34}$, Jérôme Carcopino ${ }^{35}$, Augustyna Eckmanna ${ }^{36}$, Mikołaja Gębki ${ }^{37}$, Juliusza Jundziłła ${ }^{38}$, Marka Kuryłowicza ${ }^{39}$, Borysa Łapickiego ${ }^{40}$, Ryszarda Pankiewicza ${ }^{41}$, Stanisława Stabryły ${ }^{42}$, Paula Veynego ${ }^{43}$ czy Lidii Winniczuk ${ }^{44}$, a także poświęcony temu zagadnieniu rocznik ,Vox Patrum"45.

Mając do dyspozycji tak obszerny materiał postanowiliśmy przy pomocy metody teologicznej przybliżyć jedynie nauczanie biskupa Hippony, św.

${ }^{26}$ Por. M.A. Mancuso, Il rapporto padri e figli nella prima deca di Tito Livio, „Latomus” 58 (1999) fasc. 1, 109-120.

${ }^{27}$ Por. Ch. Markschies, «Väter» im Neuplatonismus und im antiken Christentum: ein historischer Erkundungsgang mit aktuellen Hintergedanken, w: Leben und Kirche: Festschrift für Wilfried Härle zum 60. Geburtstag, hrsg. U. Andrée - F. Miege - Ch. Schwöbel, Marburg 2001, 51-66.

${ }^{28}$ Por. A. Guarino, Il «buon padre» gentiluomo?, „Labeo” 37 (1991) fasc. 2, 238-241.

${ }^{29}$ Por. A. De Francesco, Il diritto agli alimenti tra genitori e figli: un'ipotesi ricostruttiva, „Labeo” 47 (2001) fasc. 1, 28-62.

${ }^{30}$ Por. Ruiz Sánchez, Padres e hijos en la sociedad, s. 7-12.

${ }^{31}$ Por. E. Conde Guerri, El padre romano como educador: ,, iniciación para la vida perdurable”, w: Visiones mítico-religiosas del padre, s. 45-59.

${ }^{32}$ Por. A. Borgo, Famiglia, paternità e sangue: a proposito di un saggio recente di antropologia latina, „Vichiana” 12 (2010) fasc. 2, 294-297.

${ }^{33}$ Por. P.L. Carucci, Questioni di paternità nel diritto di età imperiale, „Studia et Documenta Historiae et Iuris" 78 (2012) 41-86.

${ }^{34}$ Por. P. Brown, Zmierzch starożytności, w: Historia życia prywatnego. Od Cesarstwa Rzymskiego do roku tysięcznego, red. P. Veyne, tłum. M. Rostworowska, t. 1, Wrocław - Warszawa - Kraków 1998, 223-298.

${ }^{35}$ Por. J. Carcopino, Życie codzienne w Rzymie w okresie rozkwitu cesarstwa, tłum. M. Pąkcińska, Warszawa 1960.

${ }^{36}$ Por. A. Eckmann, Starożytna rodzina grecka i rzymska, VoxP 5 (1985) t. 8-9, 29-51.

${ }^{37}$ Por. M. Gębka, Rola ojca w antycznej Grecji i Rzymie, „Poznańskie Zeszyty Humanistyczne” 20 (2013) 33-49.

38 Por. J. Jundziłł, Modele matżeństwa $w$ Rzymie pogańskim a wczesnochrześcijańskim, w: Społeczeństwo i kultura do XVI w., red. J. Śliwiński, Studia i Materiały 36, Olsztyn 1992, 9-18.

${ }^{39}$ Por. M. Kuryłowicz, Kontynuacja rodziny w państwie i prawie rzymskim okresu republiki, w: Divina et humana. Księga jubileuszowa w 65. rocznicę urodzin ks. prof. Henryka Misztala, red. A. Dębiński - W. Bar - P. Stanisz, Lublin 2001, 125-133.

${ }^{40}$ Por. B. Łapicki, Prawo rzymskie, Warszawa 1948; tenże, Władza ojcowska w starożytnym Rzymie. Część 1: Czasy królewskie. Część 2: Czasy republikańskie, Warszawa 1933.

${ }^{41}$ Por. R. Pankiewicz, Społeczno-ekonomiczne aspekty funkcjonowania rodziny wczesnorzymskiej, w: Rodzina w starożytnym Rzymie, red. K. Jakubiak, Bydgoszcz 1993, 13-39.

${ }^{42}$ Por. S. Stabryła, Zarys kultury starożytnej Grecji i Rzymu, Warszawa 2007.

${ }^{43}$ Por. P. Veyne, Cesarstwo Rzymskie, w: Historia życia prywatnego, t. 1, s. 17-221.

${ }^{44}$ Por. L. Winniczuk, Ludzie, zwyczaje i obyczaje starożytnej Grecji i Rzymu, Warszawa 1983.

${ }^{45}$ Por. VoxP 5 (1985) t. 8-9. 
Augustyna (354-430) na temat ojcostwa Bożego i ojcostwa ludzkiego. Jak można się przekonać, pomimo licznych wypowiedzi na temat ojca obecnych w pismach tego starożytnego autora, liczba opracowań poświęconych temu zagadnieniu nie jest imponująca. Niemniej jednak na uwagę zasługują prace Bernarda Bruninga ${ }^{46}$, Petera J. Burnella ${ }^{47}$, Franza K. Mayra ${ }^{48}$, Antoniego Swobody ${ }^{49}$ czy José Anoza ${ }^{50}$. Należy również zwrócić uwagę na artykuł Jacka Salija ${ }^{51}$ poświęcony ojcostwu i synostwu w pismach św. Augustyna, który jednak ogranicza się jedynie do kilku pism tegoż starożytnego autora. Stąd, by uzyskać bardziej dokładny obraz poglądów biskupa Hippony, wydaje się konieczne poszerzenie bazy źródłowej. Dlatego też, prócz pism Świętego, które uwzględnił J. Salij, zostaną przebadane następujące: Confessio$n^{52}{ }^{52}$, Contra Adimantum ${ }^{53}$, Contra duas epistolas Pelagianorum ${ }^{54}$, Contra Faustum Manichaeum ${ }^{55}$, Contra Secundinum ${ }^{56}$, Contra Julianum ${ }^{57}$, De bono

${ }^{46}$ Por. B. Bruning, „Ab utero matris meae, quae multum sperauit in te”: la maternité et la paternité d'Augustin, „Augustiniana” 54 (2004) fasc. 1-4, 379-400.

${ }^{47}$ Por. P. Burnell, Las funciones de la familia y de la sociedad civil en «la ciudad de Dios» de San Agustín, „Augustinus” 45 (2000) fasc. 176-177, 27-33.

${ }^{48}$ Por. F.K. Mayr, Trinität und Familie in De Trinitate XII, REAug 18 (1972) 51-86.

${ }^{49}$ Podajemy tylko wybrane prace: A. Swoboda, Godność ojca w pismach Plutarcha z Cheronei i św. Augustyna, VoxP 19 (1999) t. 36-37, 271-289; Aspekty wychowawcze w pismach filozoficznych Platona i autorów chrześcijańskich IV wieku (św. Augustyn, św. Hieronim), VoxP 20 (2000) t. 38-39, 463-485; Postawa ojca wobec dziecka w pismach Plutarcha z Cheronei i autorów chrześcijańskich IV wieku (św. Ambroży, św. Augustyn, św. Hieronim), PzST 10 (2001) 79-96; Wskazania moralno-pastoralne dla matżonków w pismach św. Augustyna, STHŚO 24 (2004) 295-313; Aspekty teologiczne matzeństwa i dziewictwa w pismach św. Augustyna, SSHT 37 (2004) 139-157; Źródło i prawzory sakramentu matżeństwa w nauczaniu św. Augustyna, VoxP 28 (2008) t. 52, 1049-1064; Nauka o odpowiedzialnym rodzicielstwie $w$ wybranych pismach moralno-ascetycznych św. Ambrożego, Biskupa Mediolanu (ok. 339-397) i moralno-pastoralnych św. Augustyna, Biskupa Hippony (353430), TPatr 7 (2010) 127-175.

${ }^{50}$ Por. J. Anoz, El Padre en la predicación agustiniana, „Augustinus” 47 (2002) fasc. 184-185, 5-39.

${ }^{51}$ Por. J. Salij, Ojcostwo i synostwo u św. Augustyna, ŻD 5 (1998) nr 13, 11-30.

${ }^{52}$ Por. Augustinus, Confessiones, ed. P. Knöll, CSEL 33/1, Vindobonae 1896, thum. Z. Kubiak: Święty Augustyn, Wyznania, Warszawa 1982.

${ }^{53}$ Por. Augustinus, Contra Adimantum Manichaei discipulum liber 1, ed. I. Zycha, CSEL 25/1, Vindobonae 1891, 113-190, thum. J. Sulowski: Przeciw Adimantowi, w: Pisma przeciw manichejczykom, PSP 54, Warszawa 1990.

${ }^{54}$ Por. Augustinus, Contra duas epistulas Pelagianorum libri IV, ed. C.F. Urba - I. Zycha, CSEL 60, Vindobonae 1913, 423-570.

${ }^{55}$ Por. Augustinus, Contra Faustum Manichaeum libri XXXIII, ed. I. Zycha, CSEL 25/1, 249797, thum. J. Sulowski: Św. Augustyn, Przeciw Faustusowi. Księgi I-XXI, PSP 55, Warszawa 1991; Przeciw Faustusowi. Księgi XXII-XXXIII, PSP 56, Warszawa 1991, 3-151.

${ }^{56}$ Por. Augustinus, Contra Secundinum, ed. I. Zycha, CSEL 25/2, Vindobonae 1892, 905-947, tłum. J. Sulowski, PSP 56, 161-193.

${ }^{57}$ Por. Augustinus, Contra Julianum libri VI, PL 44, 641-874, tłum. W. Eborowicz: Św. Augustyn, Przeciw Julianowi, PSP 19/1-2, Warszawa 1977. 
coniugali $^{58}$, De bono viduitatis ${ }^{59}$, De civitate Dei ${ }^{60}$, De consensu Evangelistarum $^{61}$, De doctrina christiana ${ }^{62}$, De gratia Christi et de peccato originali ${ }^{63}$, De moribus Ecclesiae catholicae et de moribus Manichaeorum ${ }^{64}$, De nuptiis et concupiscentia ${ }^{65}$, De octo quaestionibus ex Veteri Testamento ${ }^{66}$, De opere monachorum ${ }^{67}$, De sancta virginitate ${ }^{68}$, De sermone Domini in monte ${ }^{69}$, De Trinitate $^{70}$, Enarrationes in Psalmos ${ }^{71}$, Epistolae ${ }^{72}$, In Joannis Evangelium tractatus ${ }^{73}$, Opus imperfectum contra secundam responsionem Juliani ${ }^{74}$,

${ }^{58}$ Por. Augustinus, De bono coniugali liber unus, ed. I. Zycha, CSEL 41, Vindobonae 1900, $187-$ 230, thum. W. Eborowicz, w: Pisma św. Augustyna o malżeństwie i dziewictwie, red. A. Eckmann, Lublin 2003, 73-116.

${ }^{59}$ Por. Augustinus, De bono viduitatis, ed. I. Zycha, CSEL 41, 305-343, thum. T. Gacia, w: Pisma św. Augustyna o matżeństwie i dziewictwie, s. 183-222.

${ }^{60}$ Por. Augustinus, De civitate Dei libri XXII, ed. E. Hoffmann, CSEL 40/1-2, Vindobonae 1899-1900, thum. W. Kornatowski: Święty Augustyn, O państwie Bożym, t. 1-2, Warszawa 1977.

${ }^{61}$ Por. Augustinus, De consensu Evangelistarum libri IV, ed. F. Weihrich, CSEL 43, VindobonaeLipsiae 1904, tłum. J. Sulowski: Św. Augustyn, O zgodności Ewangelistów, PSP 50, Warszawa 1989.

${ }^{62}$ Por. Augustinus, De doctrina christiana, ed. J. Martin, CCL 32, Turnholti 1962, 1-167, thum. J. Sulowski: Św. Augustyn, O nauce chrześcijańskiej, Warszawa 1989.

${ }^{63}$ Por. Augustinus, De gratia Christi et de peccato originali, ed. C.F. Urba - J. Zycha, CSEL 42, Vindobonae 1902, 125-206.

${ }^{64}$ Por. Augustinus, De moribus Ecclesiae catholicae et de moribus Manichaeorum libri duo, PL 32, 1309-1378.

${ }^{65}$ Por. Augustinus, De nuptiis et concupiscentia ad Valerium libri duo, ed. C.F. Urba - J. Zycha, CSEL 42, 211-319, thum. K. Kościelniak, w: Pisma św. Augustyna o małzeństwie i dziewictwie, s. 343-390.

${ }^{66}$ Por. Augustinus, De octo quaestionibus ex Veteri Testamento, ed. D. De Bruyne, CCL 33, Turnholti 1958, 469-472, partim in PL 35, 1374.

${ }^{67}$ Por. Augustinus, De opere monachorum, ed. J. Zycha, CSEL 41, 531-595, thum. R. Szaszka, w: Św. Augustyn, Pisma monastyczne, ŹM 27, Kraków 2002, 185-267.

${ }^{68}$ Por. Augustinus, De sancta virginitate, ed. J. Zycha, CSEL 41, 235-302, thum. P. Nehring, ŹM 27, 271-348.

${ }^{69}$ Por. Augustinus, De seromone Domini in monte libri duo, ed. A. Mutzenbecher, CCL 35, Turnholti 1967, tłum. S. Ryznar - J. Sulowski, w: Św. Augustyn, O kazaniu Pana na górze. Do Symplicjana o różnych problemach. Problemy Ewangeliczne, PSP 48, Warszawa 1989, 21-130.

${ }^{70}$ Por. Augustinus, De Trinitate libri quindecim, ed. W.J. Mountain, CCL 50-50A, Turnholti 1968, tłum. M. Stokowska: Św. Augustyn, O Trójcy Świętej, Kraków 1996.

${ }^{71}$ Por. Augustinus, Enarrationes in Psalmos, CCL 38-40, ed. E. Dekkers - J. Freipont, CCL 38-40, Turnholti 1956, thum. J. Sulowski: Św. Augustyn, Objaśnienia Psalmów, PSP 37-42, Warszawa 1986.

${ }^{72}$ Por. Augustinus, Epistulae, ed. A. Goldbacher, CSEL 34/1, Vindobonae 1895; CSEL 34/2, Vindobonae 1898; CSEL 44, Vindobonae 1904; CSEL 57, Vindobonae 1911; CSEL 58, Vindobonae 1923, thum. W. Eborowicz, Św. Augustyn, Listy (1-75), Pelplin 1991.

${ }^{73}$ Por. Augustinus, In Joannis Evangelium tractatus CXXIV, ed. D.R. Willems, CCL 36, Turnholti 1954, tłum. W. Szołdrski, w: Św. Augustyn, Homilie na Ewangelię i Pierwszy List św. Jana, PSP 15/1-2, Warszawa 1977.

${ }^{74}$ Por. Augustinus, Opus imperfectum contra secundam responsionem Juliani, ed. M. Zelzer, CSEL 85/1, Vindobonae 1974; CSEL 85/2, Wien 2004. 
Quaestiones in Heptateuchum ${ }^{75}$ oraz Sermones ${ }^{76}$. Całość opracowania składać się będzie z dwóch paragrafów. W pierwszym, w oparciu o przytoczone pisma, przybliżymy nauczanie biskupa Hippony na temat ojcostwa Bożego w kontekście jego wypowiedzi o roli ojca ziemskiego. W drugim natomiast postaramy się ukazać poglądy św. Augustyna dotyczące ojcostwa ziemskiego. Ostatnia część naszej pracy zawierać będzie stosowne wnioski.

\section{CHARAKTERYSTYKA OJCOSTWA BOŻEGO}

W tym punkcie naszego opracowania zwrócimy uwagę na trzy zagadnienia. Pierwsze poświęcone będzie jego wypowiedziom na temat Boga jako Stwórcy i Rodziciela. W drugim paragrafie ukażemy jego nauczanie dotyczące przejawów działania Boga wobec człowieka, zaś w trzecim zapoznamy się ze stanowiskiem biskupa Hippony odnośnie miejsca Boga w życiu człowieka.

1. Bóg jako stwórca i rodziciel. Lektura pism św. Augustyna mająca na celu ukazanie jego nauki na temat ojcostwa przede wszystkim wskazuje, że Bóg jest ojcem ${ }^{77}$. Stąd też w oparciu o wypowiedź św. Pawła z Listu do Efezjan (3, 14-15) stwierdza, że ,zgina kolana przed Ojcem Pana naszego Jezusa Chrystusa, od którego bierze nazwę wszelkie ojcostwo (paternitas) w niebie i na ziemi" "78. Pośrednio myśl ta obecna jest także w innym miejscu, w którym zauważa, że na mocy przymierza człowiekowi zostało obiecane jedno nieprzemijające dziedzictwo polegające na tym, że ma on posiąść Boga za ojca, zaś Chrystusa jako brata ${ }^{79}$.

Prawda, iż Bóg jest ojcem uwypuklona została także poprzez dokonane porównania. Tak więc według naszego autora postępowanie Boga wobec

${ }^{75}$ Por. Augustinus, Quaestiones in Heptateuchum libri VII, ed. I. Zycha, CSEL 28/2, Vindobonae 1895, 3-506, tłum. J. Sulowski: Św. Augustyn, Problemy Heptateuchu, PSP 46-47, Warszawa 1990.

${ }^{76}$ Por. Augustinus, Sermones, PL 38, 23-1483; PL 39, 1493-1638. W Polsce opracowano w jednym tomie niewielki wybór: Św. Augustyn, Wybór mów: kazania świqteczne i okolicznościowe, thum. J. Jaworski, PSP 12, Warszawa 1973.

${ }_{77}$ Por. Augustinus, Enarrationes in Ps. 26(2), 18; 88(2), 14; Sermo 55, 5, 5; 57, 2, 2. Zob. G. Armas, Hacia una ética agustiniana del hogar, „Augustinus” 7 (1962) 158; J.L. Larrabe, Matrimonio cristiano y educación de los hijos, según san Agustín, „Augustinus” 18 (1973) 385; Salij, Ojcostwo i synostwo u św. Augustyna, s. 30. W tym miejscu pragniemy także nadmienić, iż w opublikowanej w 2013 r. pracy pt. Kobieta, żona i matka w pismach św. Augustyna (Studia i Materiały 158, Poznań 2012, 221-225) wypowiadaliśmy się na temat ojcostwa i macierzyństwa Boga. Niniejsze opracowanie ma na celu pogłębienie tematu ojcostwa Boga w odniesieniu do człowieka.

${ }^{78}$ Augustinus, De moribus Ecclesiae Catholicae et de moribus Manichaeorum I 18, 33, PL 32, 1325:, ,[...] flecto genua mea ad Patrem domini nostri Jesu Christi, a quo omnis paternitas in coelis et in terra nominatur", tłum. własne. Por. tenże, Epistula 140, 25, 62; 140, 26, 63; 175, 5; De vera religione 31, 58; Sermo 68; 165, 1, 1; Collatio cum Maximino episcopo Arianorum 3.

${ }^{79}$ Por. tenże, Epistula 243, 3. 
człowieka można przyrównać do zachowania ojca wobec własnego dziecka ${ }^{80}$, a sprawiedliwość i miłosierdzie Boże przypominają miłość matki i ojca ${ }^{81}$. Stąd też odwołując się do wspomnień ze swego dzieciństwa stwierdza, że jego matka starała się, by Bóg był dla niego ojcem ${ }^{82}$.

Już w świetle tych kilku wypowiedzi biskupa Hippony można postawić pytanie w czym wyraża się to Boże ojcostwo? Przybliżając tę prawdę podkreśla, że Bóg jest ojcem przede wszystkim dlatego, ponieważ stworzył człowie$\mathrm{ka}^{83}$. Nasz autor nie ogranicza się tylko do tego stwierdzenia, ale podkreśla, że Bóg nie tylko jest ojcem, ale kimś większym, gdyż w porównaniu z ojcem ziemskim, jest stwórcą wykorzystującym do tego celu swą potęgę ${ }^{84}$, a stwarzając przyrodę ${ }^{85}$ zachowuje prawa, które kierują jej poruszeniami ${ }^{86}$. Z kolejnej wypowiedzi autora, niewątpliwie będącej także owocem jego polemiki z manicheizmem, wynika, że Bóg, a nie szatan, jest twórcą natury ludzkieje ${ }^{87}$, którą obdarza również życiem ${ }^{88}$ i czyni to przez całe życie człowieka niezależnie od tego jakie ono jest pod względem moralnym ${ }^{89}$.

Refleksja św. Augustyna nad ojcostwem Boga nie kończy się na tych przemyśleniach, ale, jak zauważa to Josué Lui Larrabe, biskup Hippony uczył, że „fundamentem i źródłem płodności jest Bóg jako Ojciec" ${ }^{90}$. Potwierdza to lektura pism tego Ojca Kościoła, który w oparciu o Księgę Rodzaju $(1,27)$ stwierdza, że Bóg stwarzając mężczyznę i kobietę jest stwórcą płci ${ }^{91}$, a co za tym idzie, jak dostrzegał to także pelagianin Julian z Eklanum († 454), również męskości i poruszeń organów płciowych, bez których nie może dochodzić do zapłodnienia ${ }^{92}$.

W tym miejscu musimy zauważyć, że Biskup Hippony polemizując z Julianem nie zaprzeczał tym poglądom pelagiańskiego biskupa, co potwierdza

${ }^{80}$ Por. tenże, Contra Adimantum 16, 3.

${ }^{81}$ Por. tenże, Sermo 88, 21, 24.

${ }^{82}$ Por. tenże, Confessiones I 11, 17.

${ }^{83}$ Por. tenże, Enarrationes in Ps. 26(2), 18. Zob. Armas, Hacia una ética agustiniana del hogar, s. 158.

${ }^{84}$ Por. Augustinus, Enarrationes in Ps. 127, 12; Contra Julianum III 18, 34.

${ }^{85}$ Por. tenże, Contra Julianum III 24, 56.

${ }^{86}$ Por. tamże V 14, 51.

${ }^{87}$ Por. tenże, De nuptiis et concupiscentia II 6, 16; II 14, 28. Zob. Salij, Ojcostwo i synostwo $u$ św. Augustyna, s. 28.

${ }^{88}$ Por. Augustinus, De civitate Dei XXII 24, 1-2. Zob. Larrabe, Matrimonio cristiano, s. 385.

${ }^{89}$ Por. Augustinus, Contra Julianum III 24, 56; Contra duas epistolas Pelagianorum I 10, 17 - 19, 37. Zob. W. Eborowicz, Wstęp, w: Św. Augustyn, Przeciw Julianowi, Warszawa 1977, PSP $19 / 1,74$.

${ }^{90}$ J.L. Larrabe, Espiritualidad y castidad matrimonial según san Augustin (En homenaje en el XVI Centenario de su bautismo), EstA 22 (1987) fasc. 1-3, 248, tłum. własne.

${ }^{91}$ Por. Augustinus, De nuptiis et concupiscentia II 31, 53.

${ }^{92}$ Por. tenże, Opus imperfectum contra secundam responsionem Juliani V 11; V 15; V 17; De civitate Dei XXII 24, 2. Zob. Eborowicz, Wstęp, PSP 19/1, 74; Larrabe, Matrimonio cristiano, s. 385. 
jego wypowiedź w Contra Julianum ${ }^{93}$, ale starał się sprostować poglądy swego adwersarza. Uważał bowiem, że poryw skłaniający małżonków do rodzenia dzieci „o ile wywodzi się z pobożnej woli krzewienia życia jest ustanowiony przez Boga”. Natomiast, jeżeli jest on „,następstwem zamieszania namiętności, którego wolna wola nie może ani wywołać, ani opanować, wówczas pochodzi on $\mathrm{z}$ natury zranionej przewrotnością podsuniętą przez diabła”. Kontynuując swą myśl zauważa, że ,zapłodnienie następowałoby w ciele człowieka żyjącego w raju bez chorobliwej namiętności, która teraz jest konieczna w ciele tej śmierci" ${ }^{44}$. Innymi słowy, autor utrzymuje, że w raju „,człowiek mógł płodzić na rozkaz woli”, a kobieta rodziłaby „,bez bólu posiadając narządy rodne" 95 .

Dokonując analizy tych wypowiedzi musimy podkreślić, iż według biskupa Hippony komentującego Księgę Rodzaju $(1,28)$ Bóg polecił małżonkom już w raju wydawanie na świat potomstwa i udzielił im swego błogosławieństwa, „mocą którego rodzą się dzieci”"96, a to oznacza, że mężczyzna i kobieta stworzeni byli w ciałach odmiennej płci, aby rośli, rozmnażali się i napełniali ziemię, czemu nie można, zdaniem Augustyna, zaprzeczyć ${ }^{97}$. Myśl tę potwierdza kolejna wypowiedź autora, który tym razem cytuje Juliana z Eklanum nauczającego m.in., że „Bóg chciał, by przez współżycie płci rodzili się ludzie”98.

Przytoczone w tym miejscu nauczanie św. Augustyna pozwala na stwierdzenie, co również zauważa Larrabe, iż „płodność mężczyzny i kobiety jest darem Bożym, doskonałością partycypującą w Bogu, a w akcie małżeńskim jest zdolna do przyjęcia Bożego błogosławieństwa i takie od Boga otrzymała

${ }^{93}$ Por. Augustinus, Contra Julianum III 26, 60.

${ }^{94}$ Tenże, Contra Julianum III 26, 59, PL 44, 732: „Si pietate voluntatis, qua optat filios quisque suscipere; et hoc per Deum institutum: si autem perturbatione libidinis cui nec excitandae nec auferendae sufficit voluntatis arbitrium; naturae vulnus est de praevaricatione, quam diabolus persvasit, inflictum. Recte itaque a me dictum est, «Fieret sine isto morbo seminatio filiorum in corpore vitae illius, sine quo nunc fieri non potest in corpore mortis huius»”, PSP 19/1, 230. Por. tenże: De nuptiis et concupiscentia 1, 1; Opus imperfectum contra secundam responsionem Juliani V 14.

${ }^{95}$ Tenże, Opus imperfectum contra secundam responsionem Juliani V 15, CSEL 85/2, 193: „Si enim feminae sine parturitionis cruciatibus parerent, puto quod non eis membra genitalia, sed tormenta poenalia defuissent", tłum. własne.

${ }^{96}$ Tenże, Contra Julianum III 26, 60, PL 44, 732-733: „,... ] quoniam benedictio qua dictum est; Crescite, et multiplicamini, ex qua filii procreantur, ante facta est [...]”, PSP 19/1, 230. Por. Larrabe, Espiritualidad y castidad, s. 237.

${ }^{97}$ Por. Augustinus, De civitate Dei XIV 22. Zob. A. Eckmann, Wielkość i godność kobiety wedtug świętego Augustyna, w: Symbol Apostolski w pismach świętego Augustyna, red. A. Eckmann, Lublin 1999, 176; G. Stephan, Wczesnochrześcijańskie poglady o poczqtkach życia ludzkiego i ich moralne konsekwencje, „Bielsko-Żywieckie Studia Teologiczne” 2 (2000) 171.

${ }_{98}$ Augustinus, Opus imperfectum contra secundam responsionem Juliani V 15, CSEL 85/2, 190: „Deus [...] noluit nisi ut de sexibus nascerentur”, thum. własne. 
na początku stworzenia (por. Rdz 1, 26-28; 9, 1) 99, pomimo popełnionego później grzechu pierworodnego (por. Rdz 9) ${ }^{100}$.

Biskup Hippony w swych refleksjach nad ojcostwem Boga twierdzi również, że jest On także stwórcą nasienia. Nie człowiek więc, ani siła pożądliwości je tworzy, ale znajduje się ono w ciele stworzonym przez Boga ${ }^{101}$. Nasienie to, jak czytamy dalej, ożywiane jest nie przez współżycie mające na celu poczęcie dzieci, ale przez Boga. Stąd też nie człowiek, ale Bóg jest stwórcą człowieka ${ }^{102}$. Myśl ta wypowiedziana została także w polemice św. Augustyna z Julianem z Eklanum, gdzie czytamy, że „nie tylko ludzie z nasion, ale i nasiona są dziełem Boga"103.

Lektura pism św. Augustyna pozwala zauważyć, iż w jego przekonaniu Bóg jest tym, który rodzi. To rodzicielstwo Boga ma podwójny wymiar: duchowy i fizyczny. Potwierdza to nasz autor, gdy stwierdza, że ,jak dla otrzymania dziedzictwa od ziemskiego ojca musi się ktoś urodzić z łona matki cielesnej, tak aby osiagnąć wieczne dziedzictwo od Ojca-Boga, należy się urodzić z łona Kościoła”. Kontynuując tę myśl podkreśla, że „ojciec podległy śmierci rodzi przez żonę syna, który po nim nastapi”. Natomiast „Bóg rodzi przez synów, którzy po nim nie nastąpią, ale z Nim pozostaną" ${ }^{104}$. Ten aspekt duchowy rodzicielstwa Bożego nasz autor porusza także w liście adresowanym do Letusa, w którym wspominając m.in. o należnej hierarchii wartości stwierdza, że ojcem jest Bóg, a matką Kościół, z których człowiek rodzi się do życia wiecznego ${ }^{105}$.

Gdy natomiast chodzi o drugi aspekt rodzicielstwa Bożego, to nasz autor wyraźnie podkreśla, że zapłodnienie i narodzenie jest dziełem Bożym, a nie tylko ludzkim ${ }^{106}$. To więc oznacza, że Bóg jest aktywnie obecny w rodzeniu potomstwa, które nie w mniejszym stopniu jest Jego dzieckiem ${ }^{107}$, co i jego naturalnych rodziców ${ }^{108}$, a nie diabła ${ }^{109}$, co wyraźnie w swej polemice zwłasz-

\footnotetext{
${ }^{99}$ Por. tenże, Epistula 170, 7-8. Zob. Larrabe, Espiritualidad y castidad, s. 249.

${ }^{100}$ Por. Augustinus, De gratia Christi et de peccato originali II 35, 40. Zob. Larrabe, Matrimonio cristiano, s. 385.

${ }^{101}$ Por. Augustinus, De nuptiis et concupiscentia II 13, 26.

102 Por. tenże, De nuptiis et concupiscentia II 14, 28.

${ }^{103}$ Tenże, Opus imperfectum contra secundam responsionem Juliani V 11, CSEL 85/2, 181: „[...] non solum homines de seminibus, sed ipsa etiam semina, opera Dei esse [...]”, thum. własne.

${ }^{104}$ Tenże, In Joannis Evangelium tractatus 12, 5, CCL 36, 123: „Si propter hereditatem patris hominis temporalem nascitur, nascatur ex visceribus matris carnalis; si propter hereditatem patris Dei sempiternam, nascatur ex visceribus Ecclesiae. Generat per uxorem filium pater moriturus successurum; generat Deus de Ecclesia filios non successuros, sed se cum mansuros”, PSP 15/1, 186-187.

105 Por. tenże, Epistula 243, 5; Sermo 57, 2, 2; Homo Spiritalis, 415; Homo Spiritalis 414; Enarrationes in Ps. 88(2), 14. Zob. Salij, Ojcostwo i synostwo u św. Augustyna, s. 30.

${ }^{106}$ Por. Augustinus, Contra Julianum III 10, 20; V 8, 34. Zob. Eborowicz, Wstęp, PSP 19/1, 40.

${ }^{107}$ Por. Augustinus, De nuptiis et concupiscentia I 1, 1; II 13, 26.

${ }^{108}$ Por. tenże, Opus imperfectum contra secundam responsionem Juliani I 64. Zob. Larrabe, Espiritualidad y castidad, s. 248.

${ }^{109}$ Por. Augustinus, De nuptiis et concupiscentia II 6, 16; II 16, 31.
} 
cza z manicheizmem sformułował nasz autor, gdy uczył, że dziełem szatana jest grzech, natomiast „człowiek, niezależnie od tego gdzie i jak się rodzi, jest dziełem Bożym" "110. Prawda, iż Bóg powołuje do istnienia człowieka przy współpracy rodziców obecna jest, w naszym przekonaniu, także w stwierdzeniu autora, który w kontekście nauki o grzechu pierworodnym nie tylko zauważa, że „płód istnieje z płci męskiej i żeńskiej”"111, ale także uczy, że „płód pozostaje bez płci rodziców (= istnieje już od nich niezależnie) bez których nie może zaistnieć”. Jednak, jak czytamy dalej, ,całkowicie nie sprawiają, że (płód) pozostaje, ci którzy sprawili, aby on zaistniał"112.

Przytoczone w tym miejscu wypowiedzi św. Augustyna wskazuja, że wyraźnie odróżnia on działanie człowieka od działania Boga. Innymi słowy, w jego przekonaniu, choć małżonkowie dokonują aktu zapłodnienia, to jednak ostatecznie stwarza człowieka i życia jemu udziela Bóg, który jest w istocie sprawcą jego narodzin ${ }^{113}$. Ta prawda obecna jest również w jego Confessiones, gdzie wyraźnie stwierdza, że Bóg z ojca i matki ukształtował go w czasie, którego nie pamięta ${ }^{114}$.

Kolejne wypowiedzi biskupa Hippony zawierają stwierdzenia, z których wynika, że dziecko jest darem, który rodzice otrzymują od Boga ${ }^{115}$. Potwierdzenie tego znajdujemy np. w jego Confessiones, gdzie autor wyraźnie swego syna określa tym mianem ${ }^{116}$, a także w Contra Julianum ${ }^{117}$. Dziecko jest nie tylko darem Boga dla rodziców, ale obdarzając rodziców tym darem Bóg udzielił im jednocześnie władzy nad swymi dziećmi ${ }^{118}$.

${ }^{110}$ Augustinus, De nuptiis et concupiscentia I 1, 1, CSEL 42, 212: „Nam sicut peccatum, sive hinc, sive inde a parvulis trahatur, opus est diaboli: sic homo, sive hinc, sive inde nascatur, opus est Dei”, thum. Kościelniak, s. 349. Niemal te same słowa zostały zacytowane w innych miejscach, por. Augustinus, De nuptiis et concupiscentia II 2, 4; II 26, 43; Opus imperfectum contra Julianum I 22; II 23; II 24.

${ }^{111}$ Tenże, Opus imperfectum contra secundam responsionem Juliani IV 96, CSEL 85/2, 100: „Aliter enim non existit fetus, nisi ex maris et feminae sexibus”, thum. własne.

112 Tamże: „Manet enim sine parentum sexibus fetus, sine quibus tamen esse non posset; nec omnino ipsi faciunt ut maneat, qui fecerunt ut esset”, thum. własne. Por. tamże IV 100.

${ }^{113}$ Por. tenże, Contra Julianum III 24, 56.

${ }^{114}$ Por. tenże, Confessiones I 6, 7. Zob. Armas, Hacia una ética agustiniana del hogar, s. 146.

115 Por. A.G. Hamman, Życie codzienne w Afryce Pólnocnej w czasach św. Augustyna, thum. M. Stafiej-Wróblewska - E. Sieradzińska, Warszawa 1989, 102; A. Niesiołowski, Katolickie koncepcje wychowawcze w starożytności i średniowieczu, PP 233 (1939) 25.

${ }^{116}$ Por. Augustinus, Confessiones IX 6, 14, CSEL 33/1, 207: „Munera tua tibi confiteor, Domine Deus meus, creator omnium". Zob. G. Bardy, Święty Augustyn. Człowiek i dzieło, Warszawa 1955, 44; Salij, Ojcostwo i synostwo u św. Augustyna, s. 15; A. Trapè, Święty Augustyn. Człowiek duszpasterz mistyk, thum. J. Sulowski, Warszawa 1987, 127.

${ }^{117}$ Por. Augustinus, Contra Julianum IV 1, 5, PL 44, 738: „Nascitur ergo munere Dei”.

${ }_{118}$ Por. tenże, De moribus Ecclesiae catholicae et de moribus Manichaeorum I 30, 63. Zob. Bardy, Święty Augustyn, s. 123. 
2. Przejawy działania Boga wobec człowieka. Lektura pism naszego autora pozwala zauważyć, iż według niego Bóg jest nie tylko Ojcem, który stwarza, ale jest także Tym, który rządzi ${ }^{119}$, ale przede wszystkim kocha ${ }^{120}$, co nie oznacza, że spełnia każde pragnienie człowieka ${ }^{121}$.

Miłość Boga do człowieka ujawnia się także przez to, że jednoczy on ludzi między sobą. Potwierdza to biskup Hippony, gdy pisze, iż

„Bóg łączy między sobą braci węzłami religii, mocniejszymi i bardziej wewnętrznymi niż węzły krwi. Wzajemną miłością zacieśnia wszystkie związki pokrewieństwa i powinowactwa, zachowując węzły stworzone przez naturę i wolę. Bóg jednoczy nie tylko prawda, ale również pewnego rodzaju braterstwem obywateli z obywatelami, narody z narodami i wszystkich ludzi na pamiątkę ich pierwszych rodziców"122.

To ojcostwo Boga wobec człowieka wyraża się także w tym, że Bóg go karmi od początku jego istnienia. Potwierdzenie tej prawdy znajdziemy przede wszystkim w Confessiones naszego autora, w których wyznaje, że Bóg poprzez matkę i karmicielki dawał mu pokarm jaki przeznaczył dla niemowląt i to w wystarczającej ilości. Kontynuując swą myśl zauważa, że Bóg udzielił bogactw, jakich nie odmawia najniższym stworzeniom. Kobietom tym, które wobec niego spełniały swe obowiązki wychodziło na dobre to, co jemu przynosiło pożytek, który nie był z nich, ale tylko przez nie od Boga. Bóg również sprawiał, że nasz autor nie potrzebował wtedy niczego więcej, aniżeli otrzymywał, a karmicielki pragnęły obdarzać go tym, co otrzymały do Boga w obfitości ${ }^{123}$.

Pewnym istotnym uzupełnieniem tej wypowiedzi jest to, co zapisał biskup Hippony w Enarrationes in Psalmos, gdzie podkreśla nie tylko ojcostwo Boga, ale także Jego macierzyństwo przejawiające się w tym, że Bóg jak matka „ogrzewa, karmi mlekiem i obejmuje"124.

${ }^{119}$ Por. Augustinus, Enarrationes in Ps. 26(2), 18. Zob. Armas, Hacia una ética agustiniana del hogar, s. 158.

${ }^{120}$ Por. Augustinus, Sermo 286, 6, 5; Ennarationes in Ps. 93, 17. Zob. Salij, Ojcostwo i synostwo u św. Augustyna, s. 26.

${ }^{121}$ Por. Augustinus, Sermo 32, 22, 22.

${ }^{122}$ Tenże, De moribus Ecclesiae catholicae et de moribus Manichaeorum I 30, 63, PL 32, 1336: „Tu fratribus fratres religionis vinculo firmiore atque arctiore quam sanguinis nectis. Tu omnem generis propinquitatem et affinitatis necessitudinem, servatis naturae voluntatisque nexibus, mutua charitate constringes [...]. Tu cives civibus, gentes gentibus, et prorsus homines primorum parentum recordatione, non societate tantum, sed quadam etiam fraternitate coniungis", thum. własne. Por. Bardy, Święty Augustyn, s. 123.

${ }^{123}$ Por. Augustinus, Confessiones I 6, 7. Zob. Armas, Hacia una ética agustiniana del hogar, s. 146.

${ }^{124}$ Augustinus, Enarrationes in PS. 26(2), 18, CCL 38, 3: „Pater est, quia condidit, quia vocat, quia iubet, quia regit: mater, quia fovet, quia nutrit, quia lactat, quia continet", PSP 37, 210. Zob. Armas, Hacia una ética agustiniana del hogar, s. 158. Na temat macierzyństwa Boga poświęcony został osobny paragraf w pracy naszego autorstwa: Kobieta, żona i matka w pismach św. Augustyna, 
Ojcostwo Boga wobec człowieka wyraża się także w tym, że Bóg pod jego adresem udziela pouczeń ${ }^{125}$. Myśl tę ilustruje także wypowiedź autora sformułowana w oparciu o nauczanie św. Pawła (por. Ef 5, 22 - 6, 9; Kol 3, 18 - 4, 1; 1 Kor 7, 3; Tt 2, 9) oraz św. Piotra (por. 1P 3, 1-7; 2, 18), z której wynika, że Bóg przez nauczanie apostołów nie oszukuje, gdy nakazuje i upomina w jaki sposób żony powinny zachowywać się wobec swych mężów, mężowie względem żon, dzieci względem rodziców, rodzice względem dzieci, niewolnicy względem panów, a panowie względem niewolników ${ }^{126}$. Według św. Augustyna Bóg jako Ojciec ma prawo to czynić, ponieważ jest On celem dla człowieka, do którego on ma zdążać oraz jedynym i niezniszczalnym dziedzictwem, które ma posiąśćc ${ }^{127}$. Innymi słowy, według naszego autora człowiek nie jest spadkobierca Boga, jak to ma miejsce w relacjach rodzic - potomstwo, ale Boga ma posiadać za wieczne dziedzictwo.

Jak zauważa to św. Augustyn postępowanie Boga wobec człowieka nie ogranicza się tylko do pouczeń, ale obejmuje również wydawanie poleceńn ${ }^{128}$ i rozkazów ${ }^{129}$. W tym miejscu warto zauważyć, iż biskup Hippony formułując tę prawdę posłużył się także refleksjami wybitnego mówcy, filozofa i polityka rzymskiego, Marka Tuliusza Cycerona, według którego bóstwo rządzi człowiekiem ${ }^{130}$, a które w sposób werbalny przytoczył w cytowanym powyżej fragmencie zaczerpniętym z Contra Julianum.

Analizując nauczanie św. Augustyna dotyczące przejawów działania Boga względem człowieka możemy dowiedzieć się, iż Bóg może się także na niego gniewać i ranić ${ }^{131}$, choć go nie potępia, jak czyni to ziemski sędzia ${ }^{132}$. Z wypowiedzi naszego autora wynika, że ten gniew Boży, „ojcowski”, jak to określa biskup Hippony ${ }^{133}$, może mieć różne stopnie napięcia. Ilustrują to wypowiedzi Augustyna, z których wynika, że Bóg jest pogromcą ${ }^{134}$, który w gniewie prowadzi ludy ${ }^{135}$, sroży się, przeraża i woła ${ }^{136}$, napełnia uciskiem ${ }^{137}$, przeraża

\footnotetext{
s. 221-228. Tutaj ograniczamy się jedynie do uwypuklenia nauki św. Augustyna na temat ojcostwa Boga w kontekście jego wypowiedzi na temat ojca.

${ }^{125}$ Por. Augustinus, Sermo 55, 5, 5.

${ }^{126}$ Por. tenże, Epistula 157, 30.

${ }^{127}$ Por. tenże, In Joannis Evangelium tractatus 7, 7; tenże, Enarrationes in PS. 62, 10.

${ }^{128}$ Por. tenże, Contra Julianum IV 12, 61.

${ }^{129}$ Por. Augustinus, Enarrationes in Ps. 26(2), 18. Zob. Armas, Hacia una ética agustiniana del hogar, s. 158.

${ }^{130}$ Por. Marcus Tulius Cicero, De re publica III 25, 36.

${ }^{131}$ Por. Augustinus, Enarrationes in PS. 79, 5; 98, 14; 114, 5.

${ }^{132}$ Por. tamże 55, 13; 79, 5 .

${ }^{133}$ Por. tamże 55, 13, CCL 39, 5: ,[...] a te ira videtur, sed paterna".

${ }^{134}$ Por. tamże, Sermo 55, 5, 5.

${ }_{135}$ Por. tamże, Enarrationes in Ps. 55, 13.

${ }^{136}$ Por. tamże.

${ }^{137}$ Por. tamże; Sermo 5, 2.
} 
doświadczeniami $^{138}$, a także sprowadza utrapienie ${ }^{139}$ oraz smaga $^{140}$ i karci $^{141}$ człowieka swoimi biczami w przypadku jego złego postępowania ${ }^{142}$, a nawet czyni to też za grzechy rodziców ${ }^{143}$.

W kontekście tych wypowiedzi naszego autora rodzi się pytanie o cel takiego zachowania się Boga wobec człowieka. Lektura pism biskupa Hippony pozwala zauważyć, iż znajduje się w nich odpowiedź także i na to pytanie. W jego bowiem przekonaniu przejawem ojcostwa Bożego wobec żyjącego człowieka jest fakt, iż Bóg obdarza go dziedzictwem ${ }^{144}$. Nasz autor dostrzegając tę prawdę stara się ją wyjaśnić także w innym miejscu posługując się porównaniem dziedzictwa, jakie ojciec ziemski przeznacza swym dzieciom. Według naszego autora ojciec pozostawia swym dzieciom dziedzictwo, ale sam po śmierci już z niego nie korzysta. Zdarza się też, że domaga się tego, by go uważano za wielkiego i składano mu dzięki, ponieważ - jak czytamy - chciał dać to, czego nie mógł ze sobą zabrać. Zdaniem św. Augustyna, taki ojciec, gdyby mógł, to by niczego nie darował swym dzieciom. Następnie posługując się słowami psalmu $(15,5)$ zauważa, że w odróżnieniu od dziedzictwa ojca ziemskiego, dziedzictwem, które człowiek otrzymuje od Boga jest sam Bóg wraz z Chrystu$\operatorname{sem}^{145}$. To więc oznacza, że karcenie człowieka przez Boga wynikające z Jego miłości ${ }^{146}$, przyrównywanej do ognia ${ }^{147}$ i miecza ${ }^{148}$ ma na celu - podobnie jak Jego pouczenia - nie tylko jego poprawę, ale udział we wspomnianym tutaj wiecznym dziedzictwie, do którego przygotowuje poprzez tę formę pedagogii ${ }^{149}$. Myśl ta, bardziej naszym zdaniem rozbudowana, obecna jest w innym miejscu, w którym nasz autor wyjaśnia, że celem tego gniewu Bożego jest skłonienie człowieka do nawrócenia i uchronienie od niebezpieczeństwa rozkoszy i „przewrotnej pewności” ${ }^{150}$. Tak więc autor dzieląc się tymi przemyśleniami stara się przekonać słuchaczy, że celem utrapień sprowadzanych na człowieka przez Boga jest „oczyszczenie naczynia, które jest pełne nieprawości”151 i wy-

\footnotetext{
${ }^{138}$ Por. tenże, Enarrationes in Ps. 55, 13.

${ }^{139}$ Por. tamże.

${ }^{140}$ Por. tenże, Sermo 5, 2; 286, 6, 5.

${ }^{141}$ Por. tenze Sermo 55, 5, 5.

${ }_{142}$ Por. tenże, Enarrationes in Ps. 48(2), 9; 62, 10; 88(2), 2; 114, 5.

${ }^{143}$ Por. tenże, Contra Adimantum 7, 1.

${ }^{144}$ Por. tenże, Sermo 344, 2.

${ }^{145}$ Por. tenże, Sermo 55, 5, 5; 156, 15, 17; In Joannis Evangelium tractatus 7, 7.

${ }^{146}$ Por. tenże, Enarrationes in Ps. 93, 17; 118(31), 3; Sermo 5, 2. Zob. Salij, Ojcostwo i synostwo u św. Augustyna, s. 26.

${ }^{147}$ Por. Augustinus, Enarrationes in Ps. 96, 7.

${ }^{148}$ Por. tamże $149,12$.

${ }^{149}$ Por. tamże 48(2), 9; 62, 10; Sermo 286, 6, 5.

${ }^{150}$ Tenże, Enarrationes in Ps. 55, 13, CCL 38, 2: ,[...] ut in tribulationibus positi homines recurrant ad te, ne deliciis et securitate perversa seducantur", PSP 38, 357.

${ }^{151}$ Tamże 55, 13, CCL 38, 8: ,[... ] ad hoc enim exagitat tribulatio, ut exinaniat vas quod plenum est nequitia”, PSP $38,357$.
} 
pełnienie go łaską Bożą ${ }^{152}$. Innymi słowy, Bóg, w przekonaniu naszego autora, „karci tego, kogo miłuje, a doświadcza każde dziecko, które uznaje za swoje (Hbr 12, 5-7)" "153 w tym celu, by obdarzyć go zbawieniem wiecznym ${ }^{154}$. Tylko bowiem nawrócony człowiek, jak przekonuje biskup Hippony, wstępuje do domu Pańskiego, do którego zostaje przyprowadzony w Bożym gniewie, który choć przeraża człowieka doświadczeniami, to jednak napełnia go wiarą ${ }^{155}$.

Kończąc ten paragraf nie można pominąć jednej istotnie ważnej wypowiedzi autora, który mówiąc na temat sprawiedliwości i miłosierdzia Bożego przyrównuje je do miłości matki i ojca. Innymi słowy, zdaniem naszego autora, Bóg będąc sprawiedliwym nie gubi sprawiedliwego, a będąc miłosiernym przebacza grzesznikom ${ }^{156}$.

3. Miejsce Boga w życiu czlowieka. Analizując nauczanie św. Augustyna, a zwłaszcza te jego wypowiedzi, w których mówi na temat Boga i ojca ziemskiego rodzi się pytanie o miejsce Boga w życiu człowieka. Na tak postawione pytanie znajdujemy odpowiedź autora, który formułuje właściwą hierarchię wartości, według której winien postępować człowiek. Stąd np. dla naszego autora Bóg jest ważniejszy od ojczyzny. Potwierdza to jego stwierdzenie, w którym podkreśla, że w przypadku, gdyby ojczyzna coś nakazywała przeciwko Bogu, nie należy jej w takiej sytuacji słuchać ${ }^{157}$ pomimo, że ona sama jest ważniejsza od rodziców ${ }^{158}$.

Ukazana przez św. Augustyna hierarchia wartości dotyczy także relacji pomiędzy rodzicami i dziećmi. Z postawionego przez autora pytania wynika, że kimś bliskim (domesticum) dla dzieci są rodzice oraz dzieci dla rodziców ${ }^{159}$. Jednak lektura pism biskupa Hippony pozwala zauważyć, iż według niego nie tylko Bóg jest ważniejszy od ojczyzny, ale - jak przekonuje nasz autor Boga należy stawiać wyżej, aniżeli więzi pokrewieństwa ${ }^{160}$. Myśl ta obecna jest także w innej wypowiedzi autora, w której w oparciu o tekst Mt 10, 37-38 przypomina hierarchię wartości, która wskazuje na to, że miłość do rodziców, żony i dzieci nie może przysłaniać miłości do Boga. Autor podkreśla także, że Chrystus nie zniósł tej miłości, ale ją uporządkował ${ }^{161}$. To oznacza więc, że należy Go wyżej stawiać, aniżeli rodziców ziemskich, ponieważ, jak czy-

152 Por. tamże.

153 Tamże 88, (2) 2, CCL 39, 23: „[...] quem enim diligit Dominus, corripit; flagellat autem omnem filium quem recipit”, PSP 40, 150-151. Por. Salij, Ojcostwo i synostwo u św. Augustyna, s. 26.

154 Por. Augustinus, Sermo 286, 6, 5.

155 Por. tenże, Enarrationes in Ps. 55, 13.

${ }^{156}$ Por. tenże, Sermo 88, 21, 24.

${ }^{157}$ Por. tenże, Sermo 62, 5, 8.

${ }^{158}$ Por. tamże.

${ }^{159}$ Por. tenże, In Joannis Evangelium tractatus 119, 2

${ }^{160}$ Por. tenże, Enarrationes in Ps. 127, 12. Zob. Salij, Ojcostwo i synostwo u św. Augustyna, s. 28.

${ }^{161}$ Por. Augustinus, Sermo 344, 2. 
tamy, „Bóg stwarza, zaś człowiek rodzi”162. Myśl ta może być, naszym zdaniem, uzupełniona stwierdzeniem św. Augustyna, który podkreśla, że „ojciec i matka są kimś bardzo ważnym dla człowieka, pod warunkiem jednak, że w sposób właściwy wychowują i umacniają w wierze Chrystusa" ${ }^{163}$. Stąd też, w naszym przekonaniu, odwołując się do tekstu J 12, 25 nasz autor stara się wykazać, że troska o zbawienie wieczne i więź z Chrystusem są ważniejsze od miłości do rodziców i dzieci ${ }^{164}$. Postępowanie przeciwne, a więc gdy miłość do rodziców przysłania Boga, powoduje ich utratę ${ }^{165}$. Dla naszego autora bowiem ojcu ziemskiemu należy przyznać, że jest ojcem, zaś Bogu, że jest Bogiem $^{166}$. Dlatego też ojciec ziemski „nie gniewa się, gdy Boga stawia się ponad niego, ale się cieszy, że taką cześć mu się oddaje, że znajduje się Go jako tego, którego stawia się wyżej"167. Innymi słowy, autor uznając godność ojca ziemskiego, poza którym dla synów, jak wynika z postawionego pytania, nie ma nikogo droższego ${ }^{168}$, stara się podkreślić, że wyżej od niego należy jednak stawiać Stworzyciela ${ }^{169} \mathrm{i}$ być Mu posłusznym ${ }^{170}$, co nie powinno być ze strony ojca powodem do gniewu, gdy tak postępują np. jego synowie ${ }^{171}$. Powołując się z kolei na nauczanie Chrystusa, który wskazuje kto jest jego matką i kogo należy nazywać ojcem (por. Mt 12, 48-50; 23, 9), adresatowi listu - Letusowi przypomina, by zachowywał właściwą hierarchię wartości i nie stawiał wyżej od Boga matki lub ojca ${ }^{172}$. Z kontekstu wypowiedzi wynika, że nie oznacza to, iż nie należy kochać ojca ziemskiego, ale tej miłości nie należy przedkładać nad miłość do Chrystusa ${ }^{173}$ oraz nad miłość do Stwórcy ${ }^{174}$.

Biskup Hippony w swych wypowiedziach na temat przestrzegania właściwej hierarchii wartości nie pominął także relacji ojca wobec dzieci. Zdaniem naszego autora powinno się miłością otaczać dzieci, ale należy ,,jednak kochać je miłością Chrystusa, troszczyć się o nie jak Bóg i kochać w nich tylko

162 Tenże, Sermo 62, 5, 8, PL 38, 418: „Quis est, inquis, maior eo qui me generavit? Ille qui te ipsum creavit. Generat enim homo, creat Deus”, thum. własne.

${ }^{163}$ Tamże: „Primi tibi sunt pater et mater: si recte educantes, si in Christum nutrientes [...]”, tłum. własne.

${ }^{164}$ Por. tenże, Epistula 243, 5.

${ }^{165}$ Por. tamże.

${ }^{166}$ Por. tenże, Enarrationes in Ps. 127, 12. Zob. Salij, Ojcostwo i synostwo u św. Augustyna, s. 28.

${ }^{167}$ Augustinus, Enarrationes in Ps. 127, 12, CCL 40, 29: „Ne irascatur pater cum Deus illi praeponitur; imo gaudeat sibi tantum deferri, ut ille inventus esset qui ei deberet praeponi”, PSP 42/1, 47-48. Por. Salij, Ojcostwo i synostwo u św. Augustyna, s. 28-29.

${ }^{168}$ Por. Augustinus, De sermone Domini in monte II 4, 16.

${ }^{169}$ Por. tenże, Sermo 180, 6, 7.

${ }^{170}$ Por. tenże, Sermo 100, 1, 2.

${ }^{171}$ Por. tenże, Enarrationes in Ps. 70(1), 2. Zob. Salij, Ojcostwo i synostwo u św. Augustyna, s. 29.

${ }_{172}$ Por. Augustinus, Epistula 243, 9; Sermo 62, 5, 8.

${ }^{173}$ Por. tenże, Sermo 349, 7, 7.

${ }^{174}$ Por. tenże, Sermo 100, 1, 2; 344, 2. 
Chrystusa"175. W innym z kolei miejscu autor przekonuje, że ojciec winien kochać swe dzieci po bożemu, to znaczy tak, by one wraz z rodzicem czciły Boga $^{176}$. To oznacza więc, że miłość do Boga i do Chrystusa należy przedkładać ponad miłość ludzką do dzieci ${ }^{177}$. Źle bowiem, jak zauważa autor, kocha mąż i ojciec tych, których ze sobą nie prowadzi do Boga ${ }^{178}$. Z podobnie wypowiedzianą myślą spotykamy się w innym miejscu, w którym nasz autor zachęca, by nie tylko ograniczać miłość do małżonków i dzieci, gdyż taką miłością darzą się także zwierzęta i ptaki ${ }^{179}$, ale w pierwszej kolejności należy miłować Boga $^{180} . Z$ lektury pism naszego autora wynika także, że miłość do ojca czy matki nie może być większa od miłości do Kościoła, w którym człowiek zrodził się dla życia wiecznego ${ }^{181}$.

Refleksje naszego autora nie pominęły też tak ważnego tematu, jakim jest dawanie świadectwa wiary zwłaszcza w okolicznościach męczeństwa. Autor ma świadomość, że podczas prześladowań rodzice i dzieci będą starali się wzajemnie ratować przed śmiercią. Jednak zdaniem biskupa także i w tym przypadku miłości do bliskich nie należy przedkładać nad miłość do Boga ${ }^{182}$. Ta myśl obecna jest również w wypowiedzi autora, który pochwala męczennicę Perpetuę za to, że trwała w wierze i nie posłuchała swego ojca, który namawiał ją do zaparcia się wiary, by ratować życie swej córki od męczeńskiej śmierci ${ }^{183}$.

\section{OJCOSTWO ZIEMSKIE W NAUCZANIU ŚW. AUGUSTYNA}

Prezentacja przemyśleń św. Augustyna na temat ojcostwa ziemskiego podzielona zostanie na trzy punkty. W pierwszym zapoznamy się z poglądami biskupa Hippony odnośnie relacji ojcostwa ziemskiego do ojcostwa Boga, w drugim przedstawimy stanowisko św. Augustyna dotyczące dobra zrodzenia potomstwa, by w trzecim przybliżyć jego ocenę ojcostwa ziemskiego.

1. Relacja ojcostwa ziemskiego do ojcostwa Boga. Zgodnie z prawem rzymskim, jak zauważa to Łapicki, ojcostwo i władza ojcowska nie są tym samym, ponieważ ojcostwo opiera się na prawie natury, zaś władza ojcowska na prawie cywilnym. Tak więc choć z prawa natury ojcem jest ten, kto dziecko

175 Tenże, Sermo 349, 7, 7, PL 39, 1532-1533: „Amate filios vestros, amate conjuges vestras, etsi saeculariter. Nam secundum Christum amare debetis, ut secundum Deum illis consulatis, et non in eis nisi Christum diligatis [...]", tłum. własne.

${ }^{176}$ Por. tenże, Sermo 344, 2.

${ }_{177}$ Por. tenże, Sermo 344, 2; 349, 7, 7.

${ }^{178}$ Por. tenże, Sermo 344, 2.

${ }^{179}$ Por. tenże, Sermo 90, 10.

${ }^{180}$ Por. tamże.

${ }^{181}$ Por. tenże, Sermo 344, 2.

182 Por. tamże.

${ }^{183}$ Por. tenże, Sermo 281, 2, 2. Zob. Salij, Ojcostwo i synostwo u św. Augustyna, s. 28. 
spłodził (genitor), to dla prawa cywilnego ojcem czyli podmiotem władzy ojcowskiej jest ślubny mąż matki. Stąd, jak podkreśla ten autor, obok urodzenia jest niezbędne zawarcie ślubu prawnego (iustum matrimonium) przez rodziców dziecka. Ponieważ patria potestas była właściwością ustroju rzymskiego, ojcem w znaczeniu prawa cywilnego był tylko obywatel rzymski (civis Roma$n u s)$. Stąd ten, kto nie był obywatelem rzymskim, pomimo, że posiadał ius conubium, nie mógł nabyć patriae potestatis, gdyż ta była podstawą organizacji rzymskiej rodziny. Również krewnym wobec prawa cywilnego był tylko ten, kto tej władzy podlegał (cognatio civilis; agnatio). W świetle tych uwag można powiedzieć, że ówczesne prawo cywilne określało ojcostwo nie według faktu spłodzenia dziecka, którego nie da się zawsze stwierdzić, lecz w oparciu o przypuszczenie, że ojcem jest mąż matki, która zawsze jest znana ${ }^{184}$.

Św. Augustyn, jak wynika to z jego pism będących przedmiotem naszego studium, nie zagłębiał się aż tak mocno w te rozstrzygnięcia prawne, z którymi - jak musimy przyznać - nie zawsze się utożsamiał. Potwierdzenie tego znajdujemy np. w dziele De civitate Dei, w którym czytamy, że człowiek ,„przez zrodzenie drugiego człowieka staje się jego ojcem" "185, a ten jest tak samo człowiekiem, jak jego potomek ${ }^{186}$.

Przytoczone w tym miejscu wypowiedzi autora wskazują, że dla biskupa Hippony ważną rzeczą było to, aby wiadomo było kto jest ojcem dziecka. Ta pewność bowiem, która towarzyszy ojcostwu ma wielkie znaczenie w procesie wychowania dziecka ${ }^{187}$.

Nie tylko ojcostwo musi być pewne, ale samo rodzenie - jak naucza nasz autor - winno być podporządkowane prawu Bożemu. Biskup Hippony uczy, że prawo naturalne (lex naturae) nie jest czymś autonomicznym, ale jest ono podporządkowane lex divina, co pokazuje także dopuszczenie poligamii u patriarchów ${ }^{188}$, zaś pożycie małżeńskie musi być prowadzone w sposób godziwy, nie może wykraczać poza to, na co zezwala prawo Boże. Należy też mieć na uwadze, że małżonkowie są członkami Chrystusa, stworzeni przez Niego i odkupieni ${ }^{189}$.

${ }^{184}$ Por. Łapicki, Prawo rzymskie, s. 249. Na temat władzy ojcowskiej wypowiada się m.in. Władysław Bojarski i Błażej Wierzbowski (Historia prawa. Część 1: Starożytność, Toruń 1978, 174-185) oraz Kazimierz Kolańczyk (Prawo rzymskie, zaktualizował J. Kodrębski, Warszawa 20075, 243-253).

${ }^{185}$ Augustinus, De civitate Dei XIII 3, CSEL 40/1, 618: ,[...] homo autem homini gignendo parens", thum. Kornatowski, t. 2, s. 87-89.

${ }^{186}$ Por. tamże.

${ }^{187}$ Por. tenże, Opus imperfectum contra secundam responsionem Juliani V 23. Zob. Larrabe, Espiritualidad y castidad, s. 253.

188 Por. Augustinus, Sermo 51, 14, 23- 24; 51, 15, 25- 26; De bono viduitatis 7, 10. Zob. J.M. Catalálan, El matrimonio en la obra pastoral de san Agustín, „Augustinus” 34 (1989) 55.

189 Por. Augustinus, Enarrationes in Ps. 146, 2; Sermo 51, 22; 278, 9, 9. Zob. Catalálan, El matrimonio, s. 55. 
Nasz autor wypowiadając się na temat relacji ojcostwa ziemskiego do ojcostwa Bożego jednoznacznie podkreśla, że „rodziców nie nazywa się stwórcami ludzi, ani rolnika stwórcą plonów" ${ }^{190}$. Innymi słowy dzieje się to dlatego, że jedynym Stwórcą wszystkiego, o czym była mowa w poprzednim punkcie naszego opracowania, jest Bóg działający swą mocą przy współudziale rolnika czy też mężczyzny i kobiety. Potwierdza to nasz autor, gdy zauważa, że nie rodzice stwarzają człowieka, ale czyni to „troskliwie” (provide) Bóg ${ }^{191}$, który korzysta $\mathrm{z}$ ich posługi ${ }^{192}$. Tę myśl kontynuował biskup Hippony w apologetycznym dziele jakim jest De civitate Dei powstałym w latach 413-426, a więc już po napisaniu De Trinitate (399-412). Również tutaj możemy przeczytać, że pomimo iż rodzice współżyją ze sobą, to ostatecznie życia udziela Bóg ${ }^{193}$. Autor nie ogranicza się w swym nauczaniu do tych stwierdzeń, ale w swej refleksji teologicznej mając na celu wykazanie różnicy pomiędzy ojcostwem Boga, a ojcostwem ziemskim odwołuje się do tajemnicy istniejącej wewnątrz Trójcy Świętej. W kontekście nauki o Synu Bożym i Jego relacji do Boga Ojca zauważa, że w relacjach międzyludzkich „każdy syn od ojca otrzymuje to, że jest i jest synem ojca”, a żaden ojciec, jak czytamy dalej, „nie przyjmuje istnienia od syna, ale dla syna jest ojcem" "194. Omawiając z kolei zagadnienie pochodzenia Ducha Świętego nasz autor zauważa, że „u ludzi syn nie pochodzi równocześnie z ojca i z matki, lecz z ojca w matce pochodzi, i wtedy nie z matki pochodzi”. Natomiast ,gdy na ten świat wydaje go matka, wówczas nie z ojca, lecz z matki pochodzi”" ${ }^{195}$. Ta różnica pomiędzy ojcostwem Boga, a ojcostwem ziemskim widoczna jest także w innych wypowiedziach, w których autor przy pomocy antytez wyraźnie rozróżnia rodzenie, które jest właściwością rodzica ${ }^{196}$ i stwarzanie, które jest dziełem Boga ${ }^{197}$. Stąd też czytamy

${ }^{190}$ Augustinus, De Trinitate III 8, 13, CCL 50, 54. 59: „Sicut ergo nec parentes dicimus creatores hominum, nec agricolas creatores frugum, quamvis eorum extrinsecus adhibitis motibus ista creanda Dei virtus interius operetur [...]", thum. Stokowska, s. 130.

${ }^{191}$ Tenże, Contra Julianum III 20, 41, PL 44, 723: „[...] filium gignit; et Deus, cum provide hominem condit", PSP 19/1, 212.

192 Por. Augustinus, Contra Julianum III 18, 34; Opus imperfectum contra Julianum I 22; De nuptiis et concupiscentia I 1, 1; II 2, 3; II 2, 4. N. Blázquez (Feminismo agustiniano, „Augustinus” 27 (1982) 43) w swym artykule komentując nauczanie św. Augustyna w dziele De nuptiis et concupiscentia zauważa, że narodziny winny być rozumnie kontrolowane, brać pod uwagę nienaruszalność natury seksualnej małżonki, męża a także sam płód, gdyż to wszystko jest dziełem Boga.

${ }^{193}$ Por. Augustinus, De civitate Dei XXII 24, 2. Zob. Larrabe, Matrimonio cristiano, s. 385.

${ }^{194}$ Augustinus, De Trinitate II 1, 2, CCL 50, 82: „Omnis enim filius «de patre» est quod est, et patri filius est; nullus autem pater de filio est quod est sed filio pater est”, thum. Stokowska, s. 74.

${ }^{195}$ Tamże XV 27, 48, CCL 50A, : „[...] quia nec filius hominum simul et ex patre et ex matre procedit, sed cum in matrem procedit ex patre non tunc procedit ex matre, et cum in hanc lucem procedit ex matre non tunc procedit ex patre", tłum. Stokowska, s. 522. Cytat niemal w tym samym brzmieniu spotykamy w In Joannis Evangelium tractatus 99, 9.

${ }^{196}$ Por. tenże, Sermo 45, 2.

${ }^{197}$ Por. tenże, Contra Julianum III 20, 41. 
np., że ojciec ziemski ,urodził nas użyczając swego ciała, Bóg stworzył używając swej potęgi"'198, ojciec ziemski zrodził swego potomka, ale nie ukształtował ${ }^{199}$. Nie może więc dziwić, że w porównaniu z Bogiem, ojciec ziemski nie wie kogo rodzi ${ }^{200}$.

Przywoływany już przez nas Larrabe, komentując te wypowiedzi św. Augustyna zauważa, iż człowiek, który się rodzi ,jest w pewnym sensie epifanią Boga, widzialnym znakiem mocy stwórczej Boga”. Stąd rodzicielstwo ludzkie uczestniczy w rodzicielstwie Boga. To w Bogu istnieje prawdziwe rodzenie, ponieważ Bóg jest Ojcem”. Innymi słowy, zdaniem tego uczonego ,w bytach ludzkich, mężczyźnie i kobiecie, rodzenie dzieci jest partycypacją analogiczną w rodzicielstwie, które jest właściwe Bogu i dzięki temu otrzymuje swą wartość. W rodzeniu dzieci obecny jest Bóg w sposób czynny i stwórczy"201.

2. Dobro zrodzenia potomstwa. Zagadnienia, którego nie można pominąć dokonując charakterystyki ojcostwa w nauczaniu św. Augustyna jest postawa przyszłego ojca wobec mającego się począć i narodzić dziecka. Potwierdzenie tego znajdujemy w wypowiedzi św. Augustyna, który nawiązując do obecności Chrystusa na godach w Kanie zauważa, że ,ten, na którego gody Chrystus przybył, dlatego pojął żonę, aby miał dzieci i pragnął, aby szanowały tę, która je zrodzi" ${ }^{202}$. Stąd też w innym miejscu autor przekonuje, że małżonkowie współżyjąc ze sobą myślą o ojcostwie i macierzyństwie, co oznacza, że nie wykluczają potomstwa ${ }^{203}$, którego pragnienie zrodzenia zakorzenione jest głęboko w naturze ludzkiej ${ }^{204}$.

To, iż małżonkowie pragną posiadać potomstwo nasz autor dostrzegał nie tylko u przedstawicieli środowiska poza biblijnego, do których należy np. tyran Syrakuz, Dionizjos Starszy (430-367 prz. Chr.) ${ }^{205}$, ale także u patriarchów (por. Rdz 16, 3; 25, 1) ${ }^{206}$ oraz w czasach sobie współczesnych, gdy pisał, że wśród pożądań obecnych w sercach ludzi obok złota, srebra, włości,

198 Tenże, Enarrationes in Ps. 127, 12, PL 37, 1685, CCL 40, 27: „Generavit te pater accommodando carnem suam; creavit te Deus adhibendo potentiam suam", PSP 42/1, 47-48. Por. Salij, Ojcostwo i synostwo u św. Augustyna, s. 28.

199 Por. Augustinus, Sermo 344, 2.

200 Por. tamże.

${ }^{201}$ Larrabe, Matrimonio cristiano, s. 385, tłum. własne.

${ }^{202}$ Augustinus, In Joannis Evangelium tractatus 8, 5, CCL 36, 84: ,[...] ideo ducebat uxorem, ut filios procrearett; et ab eis quos ut procrearet optabat, utique honorari cupiebat", PSP 15/1, 136.

203 Por. Augustinus, De bono coniugali 3, 3. Zob. W. Eborowicz, Wstęp, w: Św. Augustyn, Wartości matżeństwa, Pelplin 1980, 19; A. Zumkeller, Augustinus in der Diskussion unserer Zeit. Zu seiner Lehre über Welt, Leib, Ehe und Jungfräulichkeit, ,Cor Unum” 28 (1970) 16.

${ }^{204}$ Por. Augustinus, Opus imperfectum contra secundam responsionem Juliani 6, 22.

205 Por. tenże, Contra Julianum V 14, 51; Retractationes II 62. Tutaj biskup Hippony nie wymienia tego tyrana z Syrakuz, ale powołując się także na lekarza Soranusa (I w.) wspomina o królu cypryjskim (Quaestiones in Heptateuchum I 93).

${ }^{206}$ Por. tenże, De doctrina christiana III 12, 20; III 18, 27; De bono coniugali 15, 17; $17,19$. 
dziedzictwa, pieniędzy, bydła, domu, żony, zaszczytów znajduje się również pragnienie potomstwa ${ }^{207} \mathrm{i}$, jeśli to możliwe, licznego ${ }^{208} \mathrm{i}$ to niezależnie od tego, że przyszłość ich dzieci jest rodzicom nieznana ${ }^{209}$. Przyszły ojciec nie pragnie potomstwa ,namiętnością ciała, lecz wolą duszy, chociaż dziecko - jak zauważa biskup Hippony - nie poczyna się bez namiętności cielesnej" ${ }^{210}$. Tę myśl autora uzupełnia kolejne zdanie, w którym polemizując z Julianem z Eklanum podkreśla, że rodzic dobrze posługuje się pożądliwością, gdy w „skromności syna rodzi" ${ }^{111}$ oraz - jak czytamy w innym miejscu - czyni to w miłości ${ }^{212}$.

Pomimo, iż rodzice ziemscy nie wiedzą kogo urodza, to jednak obecne jest w nich pragnienie, aby to potomstwo było dobre. Potwierdzenie tego znajdujemy u naszego autora, który, analogicznie jak to miało miejsce w jednej z poprzednich wypowiedzi, wymienia rzeczy, których człowiek pragnie uniknąć oraz dobra, na którym mu zależy. Tak więc nie chce on złej ziemi i złej roli, pragnie zaś posiadać dobrą ziemię, drzewo, konia, sługę, przyjaciela, a także - jako ojciec - dobrego syna, zaś jako mąż - dobrą żonę, które to dobra św. Augustyn wymienia również na końcu zdania ${ }^{213}$. Tę wypowiedź uzupełnia naszym zdaniem kolejna Mowa autora, w której stosując niemal tę samą kolejność kładzie szczególny akcent na to, czego nikt sobie w życiu nie życzy. Do wspomnianych w poprzedniej wypowiedzi dołącza jeszcze złe bydlę, złego sługę, złą szatę, złe posiadłości wiejskie, zły dom, złą żonę i złe dzieci' ${ }^{214}$, co jednak - w naszym przekonaniu - nie świadczy, że reprezentuje taką właśnie hierarchię wartości. W pewnym sensie kontynuację tej myśli znajdujemy w innym miejscu, w którym biskup Hippony wypowiada się na temat tych, którzy pragną otrzymywać błogosławieństwo od Boga. Jedni, jego zdaniem, to błogosławieństwo dostrzegają w dobrze zaopatrzonym domu, inni w zdrowiu. Są jednak i tacy, którzy pragną błogosławieństwa Bożego w postaci potomstwa i smucą się, gdy go brakuje $\mathrm{e}^{215}$. Z tego też tytułu nasz autor wymieniając różnego rodzaju lęki, które trapią człowieka - takie jak: utrata wolności, ziemi, gradobicie niszczące winnice - wymienił także lęk przed bezpłodnością żony

Zob. E. Scalco, ,, Sacramentum Connubii” et institution nuptiale; une lecture du „, De bono coniugali” et du „De sancta virginitate” de S. Augustin, EThL 69 (1993) 40.

${ }^{207}$ Por. Augustinus, Enarrationes in Ps. 51, 7; Sermo 357, 2; Contra Julianum V 10, 43; Epistula

130, 11. Zob. Catalálan, El matrimonio, s. 57.

${ }^{208}$ Por. Augustinus, Sermo 357, 2.

${ }^{209}$ Por. tenże, Contra Julianum V 10, 43; V 11, 44.

${ }^{210}$ Tenże, Contra Julianum VI 16, 50, PL 44, 851-852: ,nullo autem modo fieri potest ut carnali concupiscentia bonum hominis concupiscatur: quandoquidem nec ipsa proles libidine corporis, sed voluntate animi concupiscitur, quamvis non sine libidine corporis seminetur", PSP 19/2, 200.

${ }^{211}$ Tenże, Contra Julianum III 20, 41, PL 44, 723: „[...] cum pudice filium gignit”, PSP 19/1,

212. Por. Larrabe, Matrimonio cristiano, s. 386.

${ }^{212}$ Por. Augustinus, De consensu Evangelistarum II 3, 6.

${ }^{213}$ Por. tenże, Sermo 232, 8, 8.

${ }^{214}$ Por. tenże, Sermo 297, 5, 8.

${ }^{215}$ Por. tenże, Enarrationes in Ps. 66, 2. 
oraz przed utratą synów ${ }^{216}$. Stąd też według naszego autora zupełnie uzasadniona jest radość ojca, który nie tylko doczekał się upragnionego potomstwa, za co składa Bogu dzięki, ale także, jak czytamy, ,błogosławi Pana ten, którego żona została uwolniona od niebezpieczeństwa przy porodzie" lub też gdy chory syn powrócił do zdrowia ${ }^{217}$.

To pragnienie posiadania potomstwa może być do tego stopnia silne, że gdy nie spełniają się zwyczajne warunki do jego zrodzenia, przyszli rodzice gotowi są również adoptować dzieci, co znane jest, jak zauważa nasz autor, nie tylko w prawie cywilnym, ale potwierdza to także Pismo Święte (por. Rdz $16,1-4 ; 30,1-9)^{218}$.

3. Ocena ojcostwa ziemskiego w pismach św. Augustyna. Lektura pism naszego autora pozwala zauważyć, iż jest on przekonany o wartości ojcostwa ziemskiego. Według Bonifacio Honingsa komentującego nauczanie biskupa Hippony, „ojcostwo i macierzyństwo są wartościami, które cementują wspólnotę życia pomiędzy mężczyzną i kobietą, zaś wspólnota krwi i przyjaźń społeczna, poszerzają się poprzez prokreację"219. Potwierdzenie tej opinii znajdujemy bezpośrednio w nauczaniu św. Augustyna, który przekonuje, że m.in. do wartości małżeństwa zalicza się rodzenie potomstwa, a także naturalną społeczność, jaką tworzy małżeństwo osób odmiennej płci' ${ }^{220}$. Takie ujęcie tego zagadnienia sprawia, że św. Augustyn, jak zauważa to z kolei Wacław Eborowicz, zachowuje równowagę między oceną wartości, jaką jest wydanie potomstwa, a naturalną społecznością, jaką jest małżeństwo między osobami różnej płci. Małżeństwo bowiem, jak stwierdza ten autor, wiąże przyjaźnią mężczyznę i kobietę, czyli ich miłość i daje im prawa w dziedzinie uczuciowej i płciowej. Z tego więc względu zadania ojcowskie i macierzyńskie nadają wartość ludzką pożyciu małżeńskiemu ${ }^{221}$. Według naszego autora bowiem rodzenie potomstwa jest czynnością naturalną i dobrem, i dlatego - jak zauważa to za św. Augustynem xxx Catalálan - nie może być utożsamiana z podobną czynnością występującą u zwierząt, gdyż występuje tu wola, uczucie i rozum człowieka stworzonego na obraz i podobieństwo Boże, który dzięki posiadanej w sobie miłości i wierze potrafi zapanować nad żądzą i pożądliwością ${ }^{222}$. Myśl tę może uzupełnić kolejna wypowiedź naszego autora, który podkreśla, że „nie należy ganić ludzkiego popędu rodzenia dzieci, pod warunkiem, że

216 Por. tamże $84,11$.

217 Tamże 133, 2, CCL 40, 1936: „Quando filium desideras et nascitur, benedicis Dominum. Liberata est uxor tua a periculo partus; benedicis Dominum. Aegrotabat filius, liberatur; benedicis Dominum", PSP 42/1, 113-114.

${ }^{218}$ Por. tenże, Sermo 51, 18, 28.

${ }^{219}$ Por. B. Honings, Morale coniugale Agostiniana, „Ephemerides Carmeliticae” 20 (1969) 302.

${ }^{220}$ Por. Augustinus, De bono coniugali 3, 3.

${ }^{221}$ Por. Eborowicz, Wstęp, s. 19.

${ }^{222}$ Por. Augustinus, Sermo 229; Epistula 184 A, 1, 3. Zob. Catalálan, El matrimonio, s. 55. 
mieści się on w godziwym porządku, jakim jest małżeństwo, a nie polega na wspólnym korzystaniu z kobiet na wzór psiego zwyczaju"223.

Nie może więc dziwić stwierdzenie naszego autora, który uważał, że ojcostwo i macierzyństwo uwalnia instynkt od brutalności (malum) pożądliwości, gdy to zło czyni płodnym w sposób ,szlachetny, prawowity, przyzwoity, dla dobra wspólnego"224. Innymi słowy, św. Augustyn uważa, że małżeństwo pośród spraw ludzkich ma swoje chwalebne miejsce nie dlatego, że rodzą się dzieci, które także mogą przyjść na świat poza małżeństwem, ale dlatego, że rodzą się one w sposób uporządkowany ${ }^{225}$.

Przytoczony w tym miejscu pogląd naszego autora wskazuje, że małżeństwo, a co za tym idzie pragnienie zostania ojcem lub matką jest w pewnym sensie lekarstwem, ponieważ porządkuje pożądliwość dla dobra uczciwego zrodzenia potomstwa ${ }^{226}$. Św. Augustyn stara się także przekonać, że małżeństwo sprowadza „młodzieńczą niepowściagliwość cielesną, choć występną”, do krzewienia nowego życia. W ten sposób związek małżeński wyprowadza dobro ze zła pożądliwości, co oznacza, że pragnienie ojcostwa, a także macierzyństwa powściaga i w pewnym stopniu czyni wstydliwszym żar pożądliwości cielesnej ${ }^{227}$.

Biskup Hippony oceniając ojcostwo ziemskie był również przekonany, że na równi z macierzyństwem przekazuje ono bogactwo uczuć, delikatności oraz wychowuje ${ }^{228}$. Jednak w ocenie biskupa Hippony ojcostwo ziemskie jest tylko wartością doczesną, ponieważ rodzice, jak zauważa, gdy wydadzą na świat jedno, drugie czy trzecie dziecko, boją się rodzić dalej, by nie uczynić kolejnych dzieci żebrakami ${ }^{229}$. Nieco dalej stwierdza, że „na ziemi posiadaliśmy matkę i ojca, byśmy rodzili się do pracy i śmierci" ${ }^{230}$. Św. Augustyn, co zauważa również cytowany już Larrabe, ,występując przeciwko naturalizmowi swej epoki uczy, że ojcostwo nie wyczerpuje się jedynie w wydaniu

${ }^{223}$ Augustinus, De bono viduitatis 8, 11, CSEL 41, 317: „Filiorum quippe procreationi operam dare, non canino more per usum promiscuum feminarum, sed honesto ordine coniugali, non est in homine improbandus affectus [...]", thum. Gacia, s. 197-199. Por. Catalálan, El matrimonio, s. 55.

${ }^{224}$ Augustinus, De sancta virginitate 12, 12, CSEL 41, 244: „Habeant coniugia bonum suum, non quia filios procreant, sed quia honeste, quia licite, quia pudice, quia socialiter, procreant [...]", ŹM 27, 283. Por. E.S. Lodovici, Sessualità, matrimonio e concupiscenza in sant'Agostino, Milano 1976, 216; Swoboda, Kobieta, żona i matka w pismach św. Augustyna, s. 137.

${ }^{225}$ Por. Augustinus, Opus imperfectum contra secundam responsionem Juliani V 23.

${ }^{226}$ Por. B. Roland-Gosselin, La morale de saint Augustin, Paris 1925, 157.

${ }^{227}$ Augustinus, De bono coniugali 3, 3, CSEL 41, 191: „Habent etiam id bonum coniugia, quod carnalis vel iuvenilis incontinentia, etiamsi vitiosa est, ad propagandae prolis redigitur honestatem, ut ex malo libidinis aliquid boni faciat copulatio coniugalis", thum. Eborowicz, s. 78-79. Por. Larrabe, Matrimonio cristiano, s. 377; Lodovici, Sessualità, s. 216.

${ }^{228}$ Por. Augustinus, De sancta virginitate 12, 12. Zob. Lodovici, Sessualità, s. 216.

${ }^{229}$ Por. Augustinus, Sermo 57, 2, 2.

${ }^{230}$ Tamże, PL 38, 387: „Habebamus patrem et matrem in terra, ut nasceremur ad labores et mortem [...]", thum. wlasne. 
na świat potomstwa" ${ }^{231}$. Innymi słowy autor ten jest przekonany, że ojcostwo rozumiane tylko w czysto naturalistyczny sposób nie posiada odniesienia do zbawczego celu nadprzyrodzonego. Gdy więc rodzice chrześcijańscy tego celu nie uwzględniają i nie wychowują po chrześcijańsku swych dzieci, gdy odchodzą od głębokich relacji ojcostwa i macierzyństwa chrześcijańskiego, nie mogą stanowić dla nich przykładu małżeństwa chrześcijańskiego. Stąd też małżonkowie, zdaniem tego autora, winni się starać o to, by być prawdziwymi chrześcijanami jako małżonkowie i jako rodzice, gdyż łączą się oni w małżeństwie chrześcijańskim także jako przyszli rodzice ${ }^{232}$. Z tego też względu nasz autor kładzie szczególny nacisk na ojcostwo w wymiarze duchowym. Przykładem realizowania tego rodzaju ojcostwa jest dla biskupa Hippony św. Paweł. Komentując jego słowa zawarte w Liście do Tesaloniczan (1Tes 2, 5-7), a zwłaszcza jego działalność apostolską zauważa, że poruszony był on do głębi uczuciem zarówno ojcowskim jak i matczynym²33. Ta myśl obecna jest także, naszym zdaniem, w innej wypowiedzi naszego autora, w której zauważa, że małżeństwo chrześcijańskie nigdy nie jest bezpłodne, ponieważ uczestniczy w owocnej relacji Chrystusa z Kościołem. Znakiem takiej właśnie więzi są również składane śluby czystości, które dotyczą zaślubin Kościoła (Ecclesia), którego oblubieńcem jest sam Chrystus ${ }^{234}$.

Duchowy wymiar ojcostwa ukazują także kolejne wypowiedzi autora, w których broniąc ojcostwa św. Józefa kładzie przede wszystkim nacisk na transcendencję miłości małżeńskiej. Innymi słowy, dla św. Augustyna elementem, który ożywia i odróżnia małżeństwo chrześcijan jest miłość małżeńska oraz zgodność woli obu małżonków. To powoduje, jak zauważa Gregorio Armas, że św. Józef jest ojcem Chrystusa ponieważ złączony był z Maryją miłością czystą i gorąca, co nie sprzeciwiało się Jej wiecznemu dziewictwu. To co inni małżonkowie uzyskują przez zjednoczenie ciał, jak podkreśla ten autor, św. Józef uzyskał przez zjednoczenie serc i z tego też tytułu jego ojcostwo jest tym bardziej trwale im bardziej czyste ${ }^{235}$. Innymi słowy, św. Augustyn pragnie uwypuklić prawdę, że tak jak Maryja jest czystą matką, tak św. Józef jest czystym ojcem ${ }^{236}$. Dlatego też, jak podkreśla to nasz autor, ten kto twierdzi, że Józef nie jest ojcem ponieważ nie spłodził Syna, ten na rodzenie dzieci patrzy pod kątem rozkoszy, a nie postawy miłości ${ }^{237}$.

\footnotetext{
${ }^{231}$ Larrabe, Espiritualidad y castidad, s. 250, thum. własne.

${ }^{232}$ Por. tamże.

${ }^{233}$ Por. Augustinus, De opere monachorum 12, 13.

${ }^{234}$ Por. tenże, In Joannis Evangelium tractatus IX 2. Zob. Larrabe, Matrimonio cristiano, s. 382.

${ }^{235}$ Por. Augustinus, Sermo 51, 13, 21; 51, 16, 26; 51, 20, 30; De consensu Evangelistarum II 1, 2; Contra Faustum Manichaeum XXIII 8. Zob. Armas, Hacia una ética agustiniana del hogar, s. 470; L. Cignelli, La „,Famiglia - modello” nella Chiesa patristica, „Liber Annus” 32 (1982) 179180; Salij, Ojcostwo i synostwo u św. Augustyna, s. 27.

${ }^{236}$ Por. Augustinus, Sermo 51, 16, 26. Zob. Catalálan, El matrimonio, s. 60.

${ }^{237}$ Por. Augustinus, Sermo 51, 16, 26. Zob. Salij, Ojcostwo i synostwo u św. Augustyna, s. 27.
} 
Kończąc w tym miejscu prezentację przemyśleń św. Augustyna i mając zarazem na uwadze przytoczone wypowiedzi z jego pism, możemy też za naszym autorem zauważyć, iż zrodzenie potomstwa nie jest od czasów Chrystusa obowiązkiem, tak jak to było w czasach Starego Testamentu, który przygotowywał na przyjście Mesjasza, ponieważ czymś chwalebniejszym, jak podkreśla biskup Hippony, jest życie we wstrzemięźliwości ${ }^{238}$.

Przeprowadzone przez nas studium wypowiedzi św. Augustyna na temat ojcostwa prowadzi do następujących wniosków.

1. Według biskupa Hippony Bóg jest Ojcem, ponieważ jest Stwórcą natury i człowieka, jego płci, płodności oraz nasienia. Bóg jest również tym, który rodzi tak w wymiarze duchowym, jak i fizycznym przy współpracy rodziców przyszłego dziecka, które jest dla nich darem od Boga, nad którym mają oni, na mocy Bożego przywileju, władzę.

Bóg jest tym, który rządzi i kocha ludzi, choć nie spełnia zawsze wszystkich ich życzeń. Ojcostwo Boga wyraża się także w tym, że Bóg jednoczy ludzi między sobą, żywi, przygotowuje dziedzictwo wieczne, poucza i rozkazuje. W sytuacji, gdy człowiek źle postępuje Bóg gniewa się i karci. Celem tego karcenia jest nawrócenie człowieka i jego udział w wiecznym dziedzictwie. Bóg jako Ojciec będąc sprawiedliwym i miłosiernym zachowuje człowieka sprawiedliwego, zaś grzesznikowi przebacza.

Wypowiedzi św. Augustyna na temat ojcostwa Boga i ojcostwa ziemskiego pokazują również, że w imię właściwej hierarchii wartości należy Boga stawiać wyżej od ojczyzny, rodziców i więzów pokrewieństwa. Według biskupa Hippony Bóg ważniejszy jest także od dziecka, podobnie jak Kościół ważniejszy jest od ojca i matki. Również świadectwo wiary poświadczone męczeństwem ma większą wartość aniżeli miłość do rodziców i dzieci.

2. Biskup Hippony dokonując charakterystyki ojcostwa ziemskiego uważa, że musi być ono pewne, zaś rodzenie dzieci winno być podporządkowane prawu Bożemu. W tym rodzeniu ojciec ziemski jest jedynie współtwórca, a nie stworzycielem człowieka, ponieważ życia udziela jedynie Bóg, a rodzicielstwo ludzkie partycypuje w rodzicielstwie Boga. Dobrze rozumiane ojcostwo ziemskie nie wyklucza potomstwa, ale pragnie zrodzić je w skromności i miłości. Pragnieniem rodzica jest posiadanie dobrego potomstwo. Potomstwo, które przychodzi na świat jest znakiem błogosławieństwa Bożego i przyczyną radości, zaś jego brak rodzi smutek. Mąż i przyszły ojciec lęka się bezpłodności żony i utraty synów natomiast cieszy się z urodzenia i zdrowia dziecka, za co dziękuje Bogu. W przypadku jego braku św. Augustyn opowiada się za adopcją.

${ }^{238}$ Por. Augustinus, De bono viduitatis 8, 11. Zob. Catalálan, El matrimonio, s. 55. 
Jak wynika to z nauczania św. Augustyna ojcostwo stanowi wartość, a rodzenie potomstwa jest dobrem i nie może być utożsamiane z podobną czynnością spotykaną u zwierząt. Według naszego autora ojcostwo uwalnia od brutalności pożądliwości, porządkuje ją, przekazuje bogactwo uczuć, delikatności i wychowuje do chrześcijaństwa. Ojcostwo ziemskie chociaż jest wartością doczesna, nie wyczerpuje się w wydaniu na świat potomstwa, ponieważ posiada odniesienie do zbawczego celu nadprzyrodzonego. Nauczanie biskupa Hippony pokazuje, iż większą wartość przypisywał on ojcostwu duchowemu, aniżeli fizycznemu i stawiał jako przykład osobę św. Józefa.

\section{GOD'S AND HUMAN FATHERHOOD IN THE TERMS OF ST AUGUSTINE}

\section{(Summary)}

The presented article consists of two main parts. The first one describes the characteristic elements of God's fatherhood as it is seen by St. Augustine. Author of the study shows in this section Augustine's teaching on God as a creator and parent. Author points as well to the manifestations of God's actions towards man, to show finally the views of St. Augustine on the place of God in human life. The second part takes into the light the thoughts of Bishop of Hippo on human fatherhood and especially reveals his views on the relationship of the human fatherhood to God's fatherhood and indicates a good of the procreation. In the last part of this section, the author presents an assessment of earthly fatherhood made by St. Augustine.

Key words: Human fatherhood, Divine fatherhood, St. Augustine.

Słowa kluczowe: Ojcostwo ludzkie, ojcostwo Boże, św. Augustyn. 
